\title{
Do Audit Firms Care about Media Coverage? An Investigation of Audit Firm Response to News Coverage
}

\author{
Elizabeth N. Cowle \\ University of Arkansas \\ ecowle@walton.uark.edu \\ Caleb Rawson \\ University of Arkansas \\ crawson@walton.uark.edu \\ Stephen P. Rowe \\ University of Arkansas \\ srowe@walton.uark.edu
}

October 2020

We thank Cory Cassell, Jonathan Shipman, and workshop participants at the University of Arkansas for their helpful comments and suggestions. We also thank several anonymous audit firm partners for helpful discussions. 


\title{
Do Audit Firms Care about Media Coverage? An Investigation of Audit Firm Response to News Coverage
}

\begin{abstract}
We examine how auditors respond to news coverage of their firm and evaluate the extent to which national news outlets function as a watchdog over audit firms. We find that when media coverage includes issues specific to the audit opinion (i.e., restatements, adverse internal control opinions, fraud), audit firms respond by increasing audit attention (increased fees, reporting delay, and late filings). We find that this is amplified among clients with issues similar to those discussed in the media coverage. In contrast, we find that when news coverage does not relate to audit reporting decisions, firms decrease fees and issue audit opinions sooner. Additional analyses reveal that audit firms respond to high levels of news coverage at peer firms, suggesting that firms try to preemptively manage their reputation even when they are not under direct media scrutiny, and negative news has significant costs for firms' client growth and retention. Collectively, our evidence suggests that the news media functions as an effective informal oversight mechanism of auditing firms by driving increased auditor attention and improved audit quality.
\end{abstract}

Key words: Accounting News; Auditor Reputation; Big 4; Media Coverage 


\section{Introduction}

"No [audit] firm wants to end up on the front page of the Wall Street Journal"

- Anonymous Big 4 audit partner

"String of Firms That Imploded Have Something in Common: Ernst \& Young Audited Them"

- Front page of Wall Street Journal (10/17/2020)

Many constituents perform oversight activities of audit firms including regulators, attorneys, national associations, and news media. While an extensive body of research has examined auditors' responses to regulatory oversight and litigation, few studies have examined national news outlets as an information source and oversight body of auditors (Burke, Hoitash and Hoitash 2019). ${ }^{1}$ National news outlets are constantly looking for timely and significant stories of interest to a general audience. As such, the extent to which the news media discusses audit firms demonstrates that audit firms are associated with major events of interest. In this study, we evaluate auditors' response to media coverage by national news outlets and, consequently, the extent to which national news outlets function as a watchdog over the activities of audit firms.

Despite the lack of an official disciplining mechanism, the news media has strong influence over public perception and thus audit firm reputation. This ability to influence public perception could have a large impact on audit firms, whose value is principally derived from their reputation (e.g., DeAngelo 1981; DeFond and Zhang 2014). Negative news coverage pertaining to auditor activities may serve as a shock to auditors' reputations and, consequently, prompt firms to alter their behavior. Thus, when an auditor receives negative news coverage that impairs their reputation they have two potential responses: (1) the auditor can accept the impairment (albeit reluctantly), implicitly acknowledging that they are providing a lower value product and thus charge lower fees, or (2) the auditor can allocate additional resources to recovering lost reputation through improving

\footnotetext{
${ }^{1}$ Some accounting research has used the information content of news to proxy for characteristics of firms or managers (e.g., Hirshliefer, Lim and Teoh 2009; Rawson 2019)
} 
audit quality and avoiding similar negative media coverage in the future. While prior research on auditor reputation examines auditors' responses to infrequent and extreme audit failures, how auditors respond to reputation damage stemming from less extreme, more frequent reputation shocks such as negative news coverage is unsettled (DeFond and Zhang 2014). We expect audit firms face a trade-off following negative news coverage. Specifically, we posit that firms can either increase audit work to prevent similar issues from appearing in future news media or cut fees in an attempt to retain disgruntled clients.

Accounting research on auditors' response to national news coverage is sparse and primarily focuses on auditors' response to news coverage of their clients (e.g., Burke et al. 2019 and Cahan, Chen and Wang 2020). However, because the news media operates as an autonomous "watchdog" and publicizes events that may otherwise go unnoticed by much of the business community (Kalogeropolous et al. 2014), the extent to which national news outlets act as an oversight body of auditing firms is likely an important and previously overlooked factor in shaping auditors' behavior. For example, Smith and Emshwiller (2009) describe how their work as reporters for the Wall Street Journal exposed accounting practices at the heart of the Enron scandal and, ultimately, contributed to the demise of Enron's accounting firm, Arthur Andersen. Arthur Andersen quickly became the subject of "the most intense scrutiny by the mass media that the public accounting profession has ever faced" (Barton 2005; PAR 2002), and was eventually forced to answer for its complicity in several large-scale accounting failures and scandals. Indeed, absent oversight from national news outlets, the Andersen-Enron scandal almost certainly would not have come to light when it did, and conceivably might never have surfaced (Steiger 2002).

Oversight, in general, refers to the actions taken to review and monitor organizations in ways that ensure accountability and control quality in their actions and decisions (GAO 2003). 
Within the accounting context, oversight comes from a number of sources and operates via both direct and indirect channels (Gipper et al. 2020). The most direct channel for auditors of public companies is the regulatory oversight provided by the Public Company Accounting Oversight Board (PCAOB), which has a formal inspection schedule with power to sanction audit firms to ensure accountability. Less formal oversight is provided through litigation and news media, which rely on more informal channels of monitoring (such as investigating specific events), and also informal channels for accountability such as reputation risk. ${ }^{2}$ While accounting research has extensively explored audit firms' response to oversight from the PCAOB and litigation, ${ }^{3}$ there is limited research examining the impact of media oversight on audit firms' activities. Oversight through avenues such as the news media likely has significant consequences for auditing firms, which, in turn, are incentivized to change their behavior in order to protect their reputation.

In its capacity as an oversight body of auditing firms, the news media fulfills two important roles: (1) investigative and (2) rebroadcasting (Miller 2006). First, the news media often undertakes an investigative role whereby it performs original investigation and disseminates new information about a firm's activities. This is perhaps best evidenced by the Smith and Ermshwiller reporting that exposed the Enron-Andersen scandal. Second, the news media plays a rebroadcasting role in which it takes previously reported information from other information intermediaries and disperses it to a broader audience. For example, front page Wall Street Journal coverage in 2006 (Forelle and Bandler 2006) brought together information from firms' public

\footnotetext{
${ }^{2}$ Litigation, if it goes to trial, also has a formal accountability mechanism through court ordered reparations. However, most litigation is settled out of court, thereby making it a less formal source of accountability (Schmidt 2012).

${ }^{3}$ For example, research finds that auditors are more likely to increase audit fees and improve audit quality in response to litigation risk (Pratt and Stice 1994; Simunic and Stein 1996). Similarly, research shows that auditors improve audit quality following PCAOB inspections and undertake costly actions to remediate PCAOB deficiencies (e.g., Aobdia 2018; DeFond and Lennox 2017; Gipper et al. 2020; Krishnan, Krishnan and Song 2017; Lamoreaux 2016; Nagy 2014; Westerman, Cohen and Trompeter 2018).
} 
proxy statements, academic research, and SEC investigations to highlight the opportunistic timing of option grants resulting in more than 270 firms being implicated in "option backdating." Regardless of the role, the potential reputation shocks that accompany such oversight likely prompt a response from the auditor subject to the news coverage.

An inherent limitation in any oversight study is that oversight is often correlated with one or more underlying events. As such, the presence of oversight will naturally exacerbate any response to underlying events. In other words, it is often indistinguishable as to whether any observed response to oversight is prompted by the oversight or the underlying event itself. In the context of our study, a change in behavior driven solely by the underlying event implies that oversight is highlighting a current audit failure. However, as discussed further in Sections 3 and 4 , we identify oversight from news media as negative news articles pertaining to an event that market participants view as undesirable news rather than an actual failure on the part of the auditor. Thus, a unique feature of our setting is the ability to observe auditors' responses to informal oversight in instances when the oversight does not necessarily relate to an underlying event or audit failure.

We obtain national news coverage of the Big 4 audit firms from 2004 to 2019 by searching Factiva for coverage from leading business publications such as the Wall Street Journal and the New York Times. ${ }^{4}$ We compute a rolling 12-month total of aggregate news articles and classify articles as negative news pertaining to audit activities if it is related to restatements, adverse internal control opinions (adverse ICOs), or fraud. ${ }^{5}$ These articles tie most directly to auditors'

\footnotetext{
${ }^{4}$ Our focus on print media rather than other media sources is consisted with prior studies examining the role of national news media (e.g., Chen, Schuchard and Stomberg 2019; Core, Guay and Larcker 2008)

${ }^{5}$ We do not consider going concern opinions (GCOs) as negative news pertaining to audit activities given that the issuance of a GCO does not appear to have an impact on auditor reputation (Cowle and Rowe 2019). In addition, news articles referencing GCOs are extremely rare.
} 
performance at the individual audit level and reflect topics that clients likely perceive as negative even though they do not necessarily reflect poor audit quality.

Our first set of tests examine whether auditor attention is positively associated with the intensity of negative news coverage pertaining to audit activities. Because the news media plays an active role in collecting, aggregating, disseminating, and amplifying information about audit firms, we expect national news to prompt auditors to modify behavior following negative news coverage. Specifically, we expect to observe changes in auditor attention through higher audit fees and additional time taken to complete the audit. Consistent with our expectation, we find evidence that auditors charge higher fees and take longer to issue the audit opinion, and that clients are more likely to file late following more negative news coverage pertaining to audit activities.

We expect that the strongest effect of negative news coverage will be at firms with similar issues as those highlighted in the news. Specifically, companies that have a restatement announcement or an adverse ICO in the current year are likely most impacted when their auditor receives negative news for several reasons. First, clients with similar issues to those subject to media coverage likely receive increased audit attention to reduce the likelihood that they draw similar media attention in the future. Second, some of this attention is likely to come from the auditor's national office, which is often directly involved in audit engagements with restatements or adverse ICOs. ${ }^{6}$ Finally, the presence of a restatement or adverse ICO provides the auditor greater ability to increase attention, fees, and the filing timeline without drawing additional client irritation. We find that the firm responds by increasing audit attention (increased fees, reporting

\footnotetext{
${ }^{6}$ As one former audit partner we spoke with phrased it: "Things happening in the news are impacting leadership at the national office and then the people in the national office are driving the directives that come raining down to all the partners." Consistent with this, in response to front-page coverage by the Wall Street Journal, Ernst \& Young issued a statement that "[the firm] is launching a "redesigned audit quality strategy" that will include a continuing focus on 'developing a culture of professional skepticism." (Kowsmann, Maurer and Yang 2020).
} 
delay, and late filing) incrementally more for clients with issues similar to those discussed in the media coverage. These findings provide additional information about the mechanism through which auditors respond to news coverage. ${ }^{7}$ Together, our results suggest that auditor attention increases following the revelation of negative audit news by national news outlets and that auditors' response is targeted towards specific types of clients in response to specific news events.

Firms likely face a trade-off between appeasing current clients and protecting their reputations from future impairments when determining how to respond to negative news coverage. While our previous tests show that firms increase audit attention in response to negative news coverage, we do not necessarily expect firms to respond in the same manner when the media coverage does not highlight specific issues pertaining to audit reporting decisions. Thus, we examine how firms respond to other types of news coverage (i.e., other audit news coverage). We find that when the media coverage does not reference specific issues pertaining to audit opinions firms decrease audit fees, and perform quicker audits (i.e., charge lower fees, and issue audit opinions sooner). We interpret this response as an audit firm's attempt to appease disgruntled clients and encourage them to stay with the incumbent auditor rather than seek out a new auditor.

We also perform some additional analysis. We examine the association between restatement news coverage ${ }^{8}$ and audit quality and find that audit quality (i.e., abnormal accruals and misstatements) is worse preceding restatement news coverage and better following the news coverage, suggesting that increased news coverage follows periods of poor audit quality and

\footnotetext{
${ }^{7}$ As addressed more fully in later analysis, one concern is that auditors respond solely to the underlying event rather than the news coverage of the event. Notably, however, news stories referencing adverse ICOs are unlikely to be directly referencing an audit failure given the explicit rules of Section 404(a) of the Sarbanes-Oxley Act which dictate that management is solely responsible for establishing and maintaining adequate internal controls. Thus, given that there is no audit failure associated with an adverse ICO, it is not clear that a news event pertaining to internal controls should prompt a change in auditor attention, absent media scrutiny that threatens the auditor's reputation.

${ }^{8} \mathrm{We}$ restrict this analysis to restatement news coverage because restatements clearly reflect lower audit quality (Cowle and Rowe 2019).
} 
precedes improvements in audit quality. Next, we examine how negative news coverage affects auditor decisions regarding the areas specifically targeted by the news media. We find that audit firms are more likely to announce restatements of prior financial statements and issue adverse ICOs following news coverage about financial statement restatements and adverse ICOs, respectively. Collectively, these results suggest that oversight from national news outlets is beneficial to clients and investors through improved audit quality and increased auditor scrutiny.

In order to protect their reputation from future negative news coverage, we expect that audit firms will also change their behavior when they see another peer firm receiving high amounts of negative news coverage. Indeed, we find that high negative news coverage of one Big 4 audit firm is positively associated with audit fees, opinion delay and the likelihood of late filing at other firms. Consistent with auditors focusing attention on clients with the highest risk of generating negative new coverage, we find this effect is stronger for clients with adverse ICOs and restatements of prior financial statements. These findings demonstrate that auditors preemptively manage their reputation and also helps alleviate concerns that our main results are driven by audit firms' response to the underlying news event rather than the intensity of negative news coverage.

Finally, prior literature suggests that reputation risks should impair auditors' ability to attract and retain clients (DeFond and Zhang 2014). Consistent with negative news coverage having significant costs, we find that audit firms are less likely to attract new clients, more likely to lose existing clients, and experience lower overall client growth following negative news coverage of their firms. These findings suggest that audit firms are incentivized to change their behavior in response to negative news coverage in order to protect their reputation.

Our study makes several contributions. First, we highlight the importance of national news media as an informal oversight body and information source for auditing firms. To date, prior 
literature has focused heavily on the role of regulation and litigation as formal oversight mechanisms in shaping audit firms' behavior. By examining how coverage by the news media impacts auditor behavior and client responses, we are, to our knowledge, the first study to provide empirical evidence highlighting national news outlets as an alternative and effective oversight body of auditing firms. Further, while prior research has examined how negative news coverage of clients affects audit outcomes (Burke et al. 2019; Cahan et al. 2020), other research exploring the role of national news outlets in influencing auditor behavior is limited. Our study examines how negative news coverage of audit firms affects auditor behavior and provides important insights on how news media can shape auditor behavior and influence subsequent audit outcomes.

Second, theory proposes that the supply of audit quality is a function of auditors' competence and independence, with emphasis on independence arising from reputation incentives (DeFond and Zhang 2014). However, many studies on auditor reputation focus exclusively on extreme audit failures (e.g., Barton 2005; Skinner and Srinivasan 2012; Weber, Willenborg and Zhang 2008) and do not examine the mechanism by which those failures impact reputation (DeFond and Zhang 2014). By investigating auditors' response to negative news coverage, we take one step closer to capturing how auditor reputation is impaired and maintained. This is especially relevant given recent calls for the PCAOB to require that audit firms hire Chief Ethics Officers to help manage negative press coverage. ${ }^{9}$

Third, prior literature suggests that the media broadly influences corporate behavior and directly affects individual investing decisions by providing additional information and drawing attention to current events (Dyck et al. 2008; Engelberg and Parsons 2011; Hillert, Jacobs and Muller 2014; Tetlock 2007). Our results highlight one additional way in which the media impacts

\footnotetext{
${ }^{9}$ https://pcaobus.org/Rulemaking/Docket046/028_AAA_ASC.pdf
} 
financial markets: providing informal oversight of auditors. This finding contributes to the broader literature on the role of the media in capital markets by showing that the consequences of news coverage (e.g., reducing corruption and promoting accountability, Cordis and Warren 2014) also apply in auditing contexts. In addition, our study helps answer the call in Miller and Skinner (2015) to enhance our understanding of the monitoring role of the media.

Finally, our results have implications for audit practice. Our findings suggest that clients, investors, and regulators can use coverage from national news outlets as one way to anticipate changes in auditors' behavior. Specifically, we find that auditor attention and audit quality improve in the year following the revelation of negative audit news, which could be useful in clients' auditor selection and retention decisions, investors' investment decisions, and regulators' selection of engagements for inspection. In addition, our findings suggest auditors have strong incentives to avoid association with negative news events that could be publicized by national news outlets.

\section{Background and Research Question}

\section{National News Media in Accounting Research}

Prior research suggests that the news media serves as a public watchdog in reporting on, and uncovering, accounting fraud (Miller 2006). This research suggests that the media's autonomy enables it to report meaningful information and influence public perception, often to the benefit of the public (Franklin et al. 2005). Anecdotal evidence corroborates this view and suggests that national news outlets play an important role in policing audit firms. For example, Smith and Emshwiller (2009) describe how their work as investigative reporters for the Wall Street Journal uncovered the lies at the center of the Enron scandal, and, ultimately, contributed to the demise of Enron's accounting firm, Arthur Andersen. On October 16, 2001 Enron reported an unexpected 
loss of \$618 million - its first quarterly loss since 1997. Over the next week Smith and Emshwiller published a series of articles exposing Enron's questionable accounting practices including details about the aggressive accounting that led to Enron's previously reported profits, the liberal use of off-balance-sheet-partnerships, and misleading statements to regulators and the public. Enron's stock subsequently plummeted 60 percent and just two months later, Enron was the subject of a Securities and Exchange Commission (SEC) investigation and congressional probe (Steiger 2002).

As civil and criminal investigations into Enron's accounting practices unfolded, reporters began to scrutinize auditor Arthur Andersen for its role in the scandal. A series of news articles (e.g., Smith and Emshwiller 2001a; 2001b; 2001c; 2001d) disparaged Arthur Andersen for its complicity in the Enron fraud and revealed that Andersen auditors had extensively shredded documents in what some considered an egregious obstruction of justice. Arthur Andersen was subsequently thrust into national spotlight as the subject of "the most intense scrutiny by the mass media that the public accounting profession has ever faced" (Barton 2005; PAR 2002). Eventually forced to take accountability for its role in several large-scale accounting scandals, Arthur Andersen fell from a prestigious "Big 5" accounting firm to a permanently defunct organization (Diermier, Crawford and Snyder 2011). Indeed, absent oversight from national news outlets, the Andersen-Enron scandal and ensuing demise of Arthur Andersen almost certainly would not have come to light when it did, and conceivably might never have surfaced (Steiger 2002).

Besides investigative reporting and bringing new information to light, the news media also provides a broadcasting and amplifying role by bringing together previously dispersed information that, while already public, is disjointed or confusing. For example, on March 18, 2006, the Wall Street Journal published a front-page story about how executives conveniently received stock option grants when share prices were at their lowest level (Forelle and Bandler 2006). The timing 
of these option grants was already public information as firms are required to disclose information about option grant timing and amounts in their proxy statements. Further, the existence of such "option backdating" was already known within the academic literature (Lie 2005), and the SEC was investigating suspicious option grant behavior by the end of 2004. However, the amplification of this information by the news media and resulting option backdating scandal led to more than 270 firms being the subject of inquiries, often in response to further news articles outlining questionable option grant timing (see Ertimur, Ferri and Maber 2012 for further discussion).

Research in other disciplines suggests that the media functions as an important oversight body that influences both investor behavior and corporate decisions by making information public and influencing public perception. For example, several studies demonstrate that media coverage directly affects investors' ability to collect, process and interpret information, and in turn impacts investment decisions (e.g., Engelberg and Parsons 2011; Hillert et al. 2014; Tetlock 2007). Consistent with the media influencing capital allocation decisions, Liu and McConnell (2013) find that managers are more likely to abandon value-reducing acquisition attempts following negative press coverage. Further, media exposure has been found to influence corporate governance decisions such as director nominations and retentions (Joe, Louis and Robinson 2009) and reversals of governance violations (Dyck et al. 2008), suggesting that national news coverage functions as an effective corporate governance mechanism.

Accounting research on how auditors respond to national news coverage is sparse with existing studies primarily focused on auditors' response to news coverage of their clients. For example, some studies find that auditors are more likely to issue modified audit opinions when clients' financial statement issues (i.e., debt default and loss contingencies) are highlighted by negative press coverage (Frost 1991; Joe 2003). Burke et al. (2019) examine auditors' response to 
negative news coverage of clients' environmental, social and governance (ESG) practices and find that auditors are more likely to resign from clients that receive negative news coverage and respond to negative news about their clients' ESG practices by increasing audit planning and fees, suggesting that auditors incorporate news coverage into clients' risk assessments. Relatedly, Cahan et al. (2020) find that auditors incorporate a client's general media visibility into their client risk assessments and charge higher fees that lead to better financial reporting quality, on average. Using data on Chinese firms, Gong, Gul and Shan (2018) find evidence that auditors charge higher fees for clients with more news coverage, regardless of news tone, suggesting that more visible clients pay an audit premium. Similarly, also using data on Chinese firms, Dhaliwal et al. (2017) find that negative news coverage preceding the audit opinion increases the likelihood of clients receiving modified audit opinions, suggesting that auditors respond to an increased perception of litigation risk in the presence of negative news coverage.

Collectively, existing accounting studies provide important insights about how auditors respond to negative news coverage of their clients. However, we are unaware of any published research related to how auditors respond to negative news coverage about their own firms. Understanding how auditors respond to national news coverage of their own firms is important given that national news outlets likely play an important role in disseminating meaningful information to a large business audience and providing informal oversight to audit firms.

\section{The Role of Oversight Bodies in Shaping Auditor Behavior}

Effective oversight works by ensuring accountability and controlling quality in an organization's actions and decisions (GAO 2003). In the auditing context, oversight may be more formal, as in the case of regulators, or less formal, as in the case of attorneys. Extant accounting research has largely focused on how auditors respond to both of these types of oversight. Overall, 
this research stream concludes that this oversight is positively associated with auditor attention and audit quality, suggesting oversight from regulators and attorneys is one of the most important tools to induce changes in auditor behavior.

Many studies suggest that auditors respond to more formal oversight from regulatory bodies. For example, Lamoureaux (2016) and Krishnan et al. (2017) show that audit quality improves in response to both the threat of PCAOB inspections and actual PCAOB inspections for non-U.S. companies cross-listed in the U.S. DeFond and Lennox (2017) find that auditors increase audit fees and the issuance of adverse ICOs in response to higher inspection deficiency rates, suggesting that auditors undertake costly remediation efforts in response to PCAOB deficiencies. Likewise, Aobdia (2018) finds that auditors increase effort on both PCAOB inspected and noninspected engagements of audit offices that receive a Part 1 inspection finding, suggesting auditors directly respond to PCOAB inspection findings. Hanlon and Shroff's (2020) survey of inspectors from auditor public oversight boards in 20 countries corroborates archival evidence, concluding that auditors frequently respond to inspector feedback by changing audit procedures and quality control systems, increasing documentation, audit effort, firm-wide training, scrutiny of management estimates and modifying their audit-quality review processes.

In addition, several studies examine auditors' responses to litigation. Specifically, research finds that auditors are more likely to increase audit fees and improve audit quality in response to increased litigation risk (Pratt and Stice 1994; Simunic and Stein 1996). Furthermore, Krishnan and Krishnan (1997) show that auditors are more likely to resign from engagements with higher litigation risk, suggesting auditors rebalance their portfolios in response to heightened threats of litigation. Other research on auditors' responses to litigation finds that auditors are more likely to 
issue going concern opinions (GCOs) to financially stressed clients in order to reduce the likelihood of litigation against the audit firm (Kaplan and Williams 2013).

\section{Research Question}

While existing studies are important in advancing our understanding of how certain forms of oversight shape auditor behavior, it is unclear how auditors respond to oversight from the news media. The news media plays an important role in both investigating/uncovering new information about a firm's activities and rebroadcasting/amplifying previously known information about audit firms. Both of these roles, in turn, likely threaten auditors' reputations. Therefore, we expect that auditors likely change their behavior in response to news coverage in an attempt to mitigate the consequences associated with news-induced reputation shocks. Specifically, we anticipate that auditors face a trade-off in determining how to respond to negative news coverage of their firms: (1) the auditor can accept the reputation impairment (albeit reluctantly), acknowledge that the firm is providing a lower value product and offer a reduction in fees, or (2) the auditor can exert additional effort into recovering their reputation through improving audit quality and avoiding similar negative media coverage in the future. Following the preceding discussion, we investigate whether the increased scrutiny brought on by media coverage will lead firms to change their level of audit attention. Formally stated, we ask the following research question:

$R Q:$ Do firms adjust audit attention in response to news coverage?

\section{Research Design and Sample Selection \\ Coverage of Audit Firms in National News Outlets}

We obtain national news coverage of the Big 4 audit firms by searching for articles from major U.S. news and business publications in the Factiva database (see Appendix 2 for more details). We require that the article mention both the name of an audit firm and at least one "audit" 
related word (e.g., audit, auditor) to help ensure that the article is discussing the firm in an auditing context. ${ }^{10}$ For our primary sample, we search Factiva for articles that reference one or more of the Big 4 audit firms from 2004 to 2019. We also include search terms for various keywords that relate to negative news events, specifically terms that capture discussions regarding restatements, adverse ICOs, and fraud. Importantly, these topics reflect audit activities at the individual client level and are significant enough to involve the firm's national office, which can prompt a response across the firm, at the individual audit level (as opposed to less specific topics such as independence).

This process results in 4,253 negative audit news articles of the Big 4 audit firms in national news outlets. For descriptive purposes, in Table 1, we aggregate audit news articles by firm and year. Importantly, we observe substantial variation in the extent of audit firm news coverage both over time and between auditors.

\section{$<$ Insert Table 1 Here $>$}

Throughout our analysis, we tie news coverage to audit firms rather than specific clients because many of the news events refer broadly to audit firm failures or events that cannot be tied to specific clients or audit failures in our sample. Figure 1 graphs the amount of audit news coverage of the Big 4 audit firms by firm-quarter during our sample period. As shown in Figure 1, we observe substantial variation in news coverage of audit firms over time. We also label several specific events that occurred during our sample period that drove spikes in news coverage. Notably, the majority of these news events are not specific to any audit firms' public clients in our sample. This is important as it helps alleviate concerns that our results are a byproduct of audit

\footnotetext{
${ }^{10}$ Initial examination of articles mentioning firm names revealed that it was not uncommon for news media to exclude the term 'audit' when the firm was mentioned as a source for information (e.g., 'KMPG consulting') or when the article was not about auditing specifically (e.g., 'the accounting firm KPMG').
} 
firms responding to the underlying event and associated client. Because the events in our sample are rarely tied to specific issues at individual public clients, any observed response by auditors is likely in response to the intensity of news coverage rather than the underlying event itself.

For example, the 1MDB scandal refers to the ongoing multi-billion-dollar Malaysian government investment fund scandal. Given the connection to celebrities such as Leonardo DiCaprio and Paris Hilton, the scandal has resulted in extensive negative news coverage and various reports allege that Deloitte failed to report irregularities in the financial statements uncovered during their audits which, in turn, resulted in Deloitte's Malaysian offices being raided. The KPMG "steal the exam" scandal does not reference any specific KPMG client. Rather, the majority of coverage relates to KPMG partner David Middendorf's role in illegally obtaining advanced information about which of KPMG's audit engagements the PCAOB would select for review in its annual inspection of the firm. While the KPMG insider trading scandal in 2013 can be tied to specific clients, it does not pertain to any known audit failures as it was related to a KPMG partner tipping off a friend about material nonpublic information about KPMG clients. The 2009 jump related to the Bernie Madoff fraud only indirectly involved the Big 4 audit firms because they audited investment funds that invested in Madoff's fund. However, the audit firms still received extensive negative news coverage for having failed to uncover the Ponzi scheme earlier.

$<$ Insert Figure 1 Here $>$

\section{Research Design}

Our research question asks whether news coverage affects audit attention. To examine this, we use three distinct proxies. First, we use audit fees (FEES) because prior research suggests that audit fees are a direct input measure of auditor attention (e.g., DeFond and Zhang 2014; Doogar, 
Rowe and Sivadasan 2015). Thus, observing higher fees would be consistent with greater attention from a client's audit firm. Next, we use audit opinion delay (DELAY), and an indicator for late filings (LATE_FILE) as additional measures of auditor attention (Cassell et al. 2019). Presumably, increased auditor attention will be associated with longer audit opinion delays as the auditor spends more time on the audit, which ultimately can result in companies failing to file their annual financial statements by the deadline imposed by the SEC. To investigate our research question, we regress our three proxies for auditor attention (FEES, DELAY, LATE_FILE) on our variable of interest (\%NEGATIVE_NEWS), We estimate the following ordinary least squares (OLS) regression model: ${ }^{11}$

$$
\begin{aligned}
\text { ATTENTION }= & \beta_{0}+\beta_{1} \% N E G A T I V E \_N E W S+\beta_{2} S I Z E+\beta_{3} R O A+\beta_{4} L O S S+ \\
& \beta_{5} I N V \_R E C+\beta_{6} L E V E R A G E+\beta_{7} B U S Y+\beta_{8} I N T A N G I B L E S+ \\
& \beta_{9} \text { AFILER }+\beta_{10} \text { AFILER_LARGE }+\beta_{11} F O R \_O P S+ \\
& \beta_{12} \text { EXCHANGE }+\beta_{13} I P O+\beta_{14} A C Q U I S I T I O N S+\beta_{15} T E N U R E+ \\
& \beta_{16} \text { AUD_SIZE }+\beta_{17} I N F L U E N C E+\beta_{18} G C O+ \\
& \beta_{19} \text { FIRM_RES_ANNOUNCE }+\beta_{20} \text { AICO }+\beta_{21} \text { RES_ANNOUNCE + Year } \\
& \text { FE }+ \text { Industry FE }+\varepsilon
\end{aligned}
$$

ATTENTION is defined as audit fees (FEES), audit opinion delay (DELAY) or late filing (LATE), depending on the specification where FEES is equal to the natural logarithm of one plus the audit fees, DELAY is equal to the number of days between the fiscal year-end and the audit opinion date, and $L A T E \_F I L E$ is an indicator variable set equal to one if the client files its financial report after the SEC deadline, and zero otherwise. ${ }^{12} \%$ NEGATIVE_NEWS is equal to the sum of the number of negative news articles about the audit firm in the 12 months preceding the filing date of the individual client's financial statements divided by the total number of news articles about the audit

\footnotetext{
${ }^{11}$ Following Shipman, Swanquist, and Whited (2017), we use a linear probability model to estimate Equation (1) for our main tests even when we have binary dependent variables because this allows us to preserve sample observations and compare average treatment effects. Nevertheless, inferences are unchanged when we estimate Equation (1) using a logit model for binary dependent variables.

${ }^{12}$ LATE_FILE is constructed using the Audit Analytics non-timely filer database.
} 
firm over that same period. ${ }^{13}$ The number of negative news articles is the sum of the articles that refer to any of the following events: financial statement restatements, adverse ICOs and fraud. As discussed previously, we classify these events as "negative" because they are perceived as negative from a client's perspective, not because they necessarily reflect poor audit quality or outcomes. A positive and significant coefficient on $\beta_{1}$ would indicate that auditors increase audit attention in response to the extent of negative news coverage they have received over the preceding year.

Equation (1) includes various controls for variables that have been shown to affect auditor attention in prior literature (e.g., Cassell et al. 2019). For brevity, detailed variable definitions are provided in Appendix 1. All continuous control variables are winsorized at the $1^{\text {st }}$ and $99^{\text {th }}$ percentiles to reduce the effects of outliers. Additionally, we include year and industry fixed effects and cluster robust standard errors by company.

\section{Sample Selection}

Our primary sample is comprised of non-regulated domestic publicly traded companies with at least $\$ 1$ million in total assets that are audited by one of the Big 4 auditors from 2005 through 2019. Our final sample includes all client-year observations with necessary data in Compustat and Audit Analytics to construct the variables in Equation (1) and is comprised of 22,873 client-year observations.

\section{Descriptive Statistics}

Table 2 presents descriptive statistics for our primary sample of client-year observations. The average audit opinion delay (DELAY) is approximately 62 days after the fiscal year-end. The incidence of late financial statement filings ( $L A T E$ ) is 5.7 percent. Negative audit news articles (\%NEGATIVE_NEWS) are approximately 9.3 percent of total news coverage about an individual

\footnotetext{
${ }^{13}$ Results are robust to alternatively scaling negative news articles by the total number of audit specific news articles.
} 
firm in a given year, on average. Consistent with prior research (e.g., Aobdia 2019), the incidence of 8-K ("Big R") misstatements (MISSTATE_8K) is 2.2 percent.

$<$ Insert Table 2 Here $>$

\section{Results}

Our research question asks whether news coverage is associated with auditor attention. Specifically, we expect that the heightened scrutiny brought on by media oversight will lead firms to increase audit attention on their clients. To investigate this, we estimate Equation (1) and present the results in Table 3. We are interested in the association between audit firm \%NEGATIVE_NEWS and audit attention. As shown in Table 3, Column 1, we find a positive and significant association between our variable of interest (\%NEGATIVE_NEWS) and the amount of audit fees charged (FEES), suggesting that auditors increase audit fees following negative news coverage. This is consistent with auditors responding to heightened oversight by media outlets by expending additional costly effort to reduce future negative outcomes.

Next, we examine audit opinion delay (DELAY) and the incidence of late filings (LATE) following negative news coverage as two additional measures of audit attention. The results from our estimation of Equation (1) using DELAY and LATE are presented in Table 3, Columns 2 and 3, respectively. We find a positive and significant association between the extent of negative news coverage and both the average audit opinion delay and incidence of late filings (i.e., $p<0.01$ across both specifications). Taken together, results in Table 3 are consistent with firms increasing audit fees and taking longer to complete their audits in periods after receiving a higher proportion of negative media coverage.

\footnotetext{
$<$ Insert Table 3 Here $>$
} 
Next, we expect that audit firms' responses to negative news coverage will likely be targeted toward the specific areas that are being covered by the media, presumably because of heightened scrutiny around these types of events. Furthermore, because specific events like restatements and adverse ICOs often require national office consultation, audit firms are likely able to attribute the cost of additional effort to problems at the client rather than news coverage of the related issues. Nevertheless, we expect firms to charge incrementally more to these clients than they would have absent the intensity of negative news coverage. Thus, to examine auditors' response to negative news coverage related to specific events, we re-estimate Equation (1) in Table 4 but replace our variable of interest with an interaction of \%AICO_NEWS x AICO in Panel A and $\%$ RESTATEMENT_NEWS x RES_ANNOUNCE in Panel B. ${ }^{14}$

As shown in Table 4, Panel A, the coefficient estimate on the interaction term $\left(\% A I C O \_N E W S \times A I C O\right)$ is positive and significant across all three specifications (i.e., $\mathrm{p}<0.10$ in Column 1; $\mathrm{p}<0.01$ in Columns 2 and 3). This result suggests that audit attention (i.e., fees, audit opinion delay and late filing) increases incrementally more for clients that received an adverse ICO when the audit firm receives more negative coverage related to adverse ICOs. Similarly, as shown in Table 4, Panel B, the coefficient estimates on the interaction term capturing restatement announcements of prior period financial statements and restatement news is positive and significant across two of three specifications (i.e., p $<0.01$ in Columns 2 and 3). This result suggests that audit attention (i.e., audit opinion delay and late filing) increases incrementally more for clients that have restatements of prior period financial statements when the audit firm receives more negative news coverage related to restatements.

$<$ Insert Table 4 Here $>$

${ }^{14}$ We exclude fraud news from this analysis given that it is unclear whether fraud can be tied to specific issues at a client. 
Collectively, the results from the previous analyses suggest that auditors increase attention in response to negative news coverage and that this response is targeted toward specific areas of the negative news coverage. This observed change in auditor behavior is likely in response to heightened scrutiny prompted by media coverage and is consistent with the news media providing an important oversight role that influences auditor behavior.

\section{Other Audit News}

As discussed previously, when determining how to respond to national news coverage, firms likely face a trade-off between protecting themselves from future reputation impairments by increasing audit effort and appeasing current clients who may find negative news coverage objectionable. While our previous tests show that firms increase audit attention in response to negative news coverage pertaining to audit activities, we acknowledge that auditors are discussed in the national news media for far more than their audit reporting activities. Thus, because we do not necessarily expect firms to respond in the same manner when the media coverage does not highlight specific issues pertaining to audit reporting decisions, we also examine how auditors respond to other audit news coverage, or news coverage that does not pertain to a negative audit event (i.e., news that does not mention restatements, adverse ICOs or fraud). Reviews of other audit news coverage revealed that this type of coverage is generally still somewhat negative, although it focuses on issues notably more distant from the performance of audit tasks and auditor reporting decisions (e.g., auditor independence). Notably, it is not clear that other audit news coverage can be directly tied to changes in behavior that need to be made across individual audit 
engagements. Thus, we do not expect firms to respond in the same manner to this type of news as they do to negative news related to the conduct or reporting decisions at the individual audit level.

To examine how firms respond to other audit news, we re-estimate Equation (1) but replace our variable of interest with \%OTHER_NEWS, equal to the sum of the number of news articles about the audit firm that reference audit but do not refer to financial statement restatements, adverse ICOs and fraud in the 12 months preceding the date of the individual client's financial statements divided by the total number of news articles about the audit firm over that same period. Results from this analysis are presented in Table 5.

As shown in Table 5, coefficient estimates on our variable of interest are negative and statistically significant in Columns 1 and 2 (i.e., $\mathrm{p}<0.01$ ), suggesting that firms decrease their fees and have shorter opinion delays following media coverage that does not mention specific issues pertaining to audit opinions. This type of response is consistent with audit firms seeking to appease their current clients by lowering fees and issuing their audit report sooner following a potential challenge to their reputation by the news media.

$<$ Insert Table 5 Here $>$

\section{Additional Analysis}

\section{Negative News Coverage and Audit Quality}

Prior research suggests that coverage by national news outlets likely helps shape public perceptions of audit firms (Dyck et al. 2008). Improving audit quality is one way in which audit firms can help manage public perception of their firm, particularly in light of restatement news coverage. As such, we expect that auditors will respond to the prevalence of restatement news by improving audit quality. To investigate this, we begin by examining whether news coverage 
mentioning restatements is associated with a higher incidence of misstatements (e.g., Aobdia 2019;

Francis 2011) and larger abnormal accruals (e.g., Aobdia 2019; Dechow, Sloan and Sweeney 1995) in the most recently reported financial statements (i.e., we examine whether news coverage is a credible signal of audit quality). We then examine whether misstatements and accruals decrease in the subsequently issued financial statements (the same period that we examined auditor responses for in our earlier tests).

In untabulated analysis, we find that Big R misstatements are higher in the period preceding negative news events mentioning restatements and decrease significantly in the period following the negative news coverage. We also find that unsigned discretionary accruals are larger in the period preceding negative news events that mention restatements and observe a decrease in unsigned discretionary accruals following negative news coverage. Taken together, results from this analysis suggest both that restatement news follows periods of worse auditing (i.e., periods with more restatements) and that auditors improve audit quality in response to oversight from national news outlets. Importantly, auditors' response is beneficial to clients and investors in the form of improved audit quality, providing further evidence that the news media functions as an effective informal oversight body of auditing firms.

\section{Negative News Coverage and Auditor Reporting Decisions}

Next, we examine how negative news coverage affects auditor reporting decisions. We expect news coverage to influence auditors' reporting decisions, particularly decisions related to the topic of the news coverage. To investigate this, we replace our variable of interest in Equation (1) with either \%RESTATEMENT_NEWS or \%AICO_NEWS and our dependent variable with either RES_ANNOUNCE, an indicator variable set equal to one if the prior period financial 
statements are restated in that year, or $A I C O$, an indicator variable set equal to one if the client receives an adverse ICO, depending on the news coverage.

Results from this analysis are presented in Table 6. As shown in Table 6, coefficient estimates on our variables of interest are positive and significant (i.e., $p<0.05$ in Columns 1 and 2), suggesting that audit firms are more likely to announce restatements of prior period financial statements and issue adverse ICOs following news coverage that refers to financial statement restatements and adverse ICOs, respectively. Collectively, this evidence suggests that oversight from national news outlets influences auditor reporting decisions, particularly in areas targeted by the news coverage.

\section{$<$ Insert Table 6 Here $>$}

\section{Negative News Coverage of Peer Audit Firms}

In order to protect their reputation from future negative news coverage, we expect that audit firms will change their behavior when they see another peer firm receiving high amounts of negative news (i.e., another Big 4 firm). To examine this notion, we identify the audit firm receiving the most negative news coverage in a given period and capture the amount of negative news that this firm receives. We then examine whether the other audit firms respond to this firm's high amount of negative news. Thus, our variable of interest is the highest amount of negative news coverage received by a peer firm (\%NEGATIVE_NEWS_PEER). We then reperform our main tests with a sample of only the other three firms that did not receive the highest negative news coverage in a given period (i.e., we drop the audit firm that received the highest amount of negative news coverage during the period). Importantly, this analysis also helps reduce endogeneity concerns about specific events driving both negative media coverage and specific auditor responses. Specifically, the amount of peer negative news is unlikely to be associated with 
audit quality at a competitor firm except through differences in audit attention related to firms trying to protect themselves from future negative news coverage.

Table 7 presents results from examining firms' responses to high negative news coverage of peer audit firms. As shown in Panel A, high negative news coverage of a peer firm is positively associated with audit fees, audit opinion delay and the likelihood of late filing for the other three audit firms (i.e., audit attention increases among the three audit firms that did not receive the highest amount of negative news coverage during that period). Results in Panel B show that the effect on opinion delay and late filing is stronger for clients receiving an adverse ICO when the negative news of the peer firm relates to adverse ICOs (AICOx\%AICO_NEWS_PEER). Similarly, results presented in Panel $\mathrm{C}$ show that the effect on audit fees, opinion delay and late filing is stronger for clients that end up announcing restatements of prior period financial statements when the negative news coverage of the peer firm pertains to restatements (RES_ANNOUNCE $x$ RESTATEMENT_NEWS_PEER). ${ }^{15}$

\section{$<$ Insert Table 7 Here $>$}

Taken together, and consistent with the media playing an important oversight role, results from this analysis support the notion that firms respond to negative news coverage, not only pertaining to their own firm, but other large audit firms as well. Importantly, this analysis helps alleviate the concern that our main results are being driven by audit firms' response to an underlying news event rather than the amount of news coverage about the event. By dropping the audit firm that is the primary focus of the underlying negative event and news coverage from this test, we provide further evidence that firms respond to negative news coverage in order to protect their reputation, even if that negative news coverage focuses on a peer audit firm. In other words,

\footnotetext{
${ }^{15}$ Due to potential concerns with the decrease in intra-year variation, we re-perform all specifications in this analysis without year fixed effects and find substantially similar results.
} 
it is unlikely that changes in an audit firm's behavior are in response to an underlying event that occurred at a peer firm. ${ }^{16}$

\section{Negative News Coverage and Client Switching Behavior}

An assumption throughout our previous tests is that audit firms are incentivized to change their behavior in response to negative news coverage in order to protect their reputations. This assumption implies that negative news coverage has significant consequences for audit firms. Therefore, we examine the impact that negative news coverage has on audit firms' reputation by examining how negative news coverage affects client switching behavior and, consequently, overall audit firm client growth. To do this, we re-estimate Equation (1) but replace our dependent variable with INCOMING_CLIENT, OUTGOING_CLIENT or OVERALL_FIRM_GROWTH (depending on the specification) and examine whether negative news coverage affects auditors' ability to attract and retain clients. If negative news coverage has a negative impact on auditors' reputations, we expect it to have a negative association with firm growth and new clients and a positive association with dismissals. Results from this analysis are presented in Table $8 .^{17}$

Results from this analysis reveal that following negative news coverage, audit firms are less likely to attract new clients, more likely to lose clients, and experience lower overall client growth. Specifically, as shown in Table 8, Column 1 audit firms are less likely to engage new clients following negative news coverage. Further, as shown in Table 8. Column 2, existing clients are more likely to switch auditors when their audit firms has more negative news coverage. Finally, as shown in Table 8, Column 3, audit firms have lower overall client growth when there is more

\footnotetext{
${ }^{16}$ For example, if KPMG has the highest negative news coverage during a given period, it is unlikely that Deloitte would increase audit attention on their audit engagements in response to an underlying event that occurred at a KPMG client. It is much more likely that changes in audit attention among clients of Deloitte are made in an effort to prevent Deloitte from receiving future negative news coverage that would paint the firm in a negative light and thus threaten the firm's reputation.

${ }^{17}$ We also drop audit firm tenure from our control variables because tenure is highly negatively correlated with client growth (i.e., new clients have low tenure).
} 
negative news coverage about their firm. Taken together, these findings suggest that coverage by national news outlets has significant costs for audit firms and decreases auditors' ability to attract and retain clients. Such consequences likely incentivize auditors to change their behavior in order to protect their reputations.

\section{$<$ Insert Table 8 Here $>$}

\section{Influential Clients}

Throughout our analysis, we focus on an on average effect, given that we expect audit firms to respond to negative news coverage regardless of individual client importance. Nevertheless, we do expect that our main effect will be stronger for companies that are more important or influential to the audit office as these are the clients that are even more likely to receive national audit office attention and bear the greatest risk to the local office's reputation. Therefore, we re-estimate Equation (1) and replace our variable of interest with an interaction of INFLUENCE $\mathrm{x}$ $\% N E G A T I V E \_N E W S$ where INFLUENCE is an indicator variable set equal to one if a client's ratio of audit fees to total audit fees collected by an office is higher than the median value.

Results from this analysis indicate that audit fees and audit opinion delay are indeed higher for more influential clients when the audit firm also has more negative news coverage and are consistent with audit firms focusing incrementally more attention on the clients that are most important from a reputational perspective.

\section{Conclusion}

In this study, we investigate how auditors respond to negative news coverage and examine the extent to which national news outlets function as a watchdog over the activities of audit firms. We find evidence that auditors increase audit attention and improve audit quality following 
negative news coverage of their firm and that this effect is stronger among clients with audit reporting issues similar to those highlighted in the news coverage. We also find that auditors decrease fees and issue audit opinions sooner when the news coverage does not relate to specific audit activities. Taken together, our findings suggest audit firms face a trade-off in determining how to respond to news coverage and change their behavior in an attempt to either appease current clients or protect their reputations from future shocks. Importantly, we show that the news media functions as an effective informal oversight body of auditing firms and that clients and investors benefit from this oversight in the form of improved audit quality.

By examining how coverage by the news media impacts auditor behavior and client responses, we are the first study to provide empirical evidence highlighting national news outlets as an alternative and effective oversight body of audit firms. Our study contributes to extant literature and provides important insights on how national news outlets can shape auditor behavior and influence subsequent audit outcomes. Additionally, many studies on auditor reputation focus exclusively on extreme audit failures and therefore do not link reputation to actual audit quality (e.g., Barton 2005; DeFond and Zhang 2014; Skinner and Srinivasan 2012; Weber et al. 2008). In contrast, by investigating auditors' response to negative news coverage, we provide empirical evidence supporting the notion that reputation concerns do improve audit quality. Furthermore, our results highlight one additional way in which the news media impacts financial markets: providing informal oversight of auditing firms. Finally, our findings suggest that clients, investors, and regulators can use coverage from national news outlets as one way to anticipate changes in auditors' behavior. Future studies could examine how auditors respond to news stories about other non-audit events, including those that cast the firm in a positive light and how second-tier and other auditors respond to national news coverage of their firms. 


\section{References}

Aobdia, D. 2018. The Impact of the PCAOB Individual Engagement Inspection Process-Preliminary Evidence. The Accounting Review 93 (4): 53-80.

Aobdia, D. 2019. Do practitioner assessments agree with academic proxies for audit quality? Evidence from PCAOB and internal inspections. Journal of Accounting and Economics 67 (1): 144-174.

Barton, J. 2005. Who Cares about Auditor Reputation?. Contemporary Accounting Research 22: 549-586.

Burke, J. J. R. Hoistash and U. Hoitash. 2019. Auditor Response to Negative Media Coverage of Client Environmental, Social, and Governance Practices. Accounting Horizons 33 (3): 1-23.

Cahan, S. F., C. Chen, and R. Wang. 2020. Does Media Exposure Affect Financial Reporting Quality Through Auditors? Journal of Accounting, Auditing and Finance: forthcoming.

Cassell, C., E. Hunt, G. Narayanamoorthy, and S. P. Rowe. 2019. A Hidden Risk of Auditor Industry Specialization: Evidence from the Financial Crisis. Review of Accounting Studies 24 (3): 891-926.

Chen, S., K. Schuchard and B. Stomberg. 2019. Media Coverage of Corporate Taxes. The Accounting Review 94 (5): 83-116.

Cordis, A. S. and Warren, P. L. 2014. Sunshine As Disinfectant: The Effects of State Freedom of Information Act Laws on Public Corruption. Journal of Public Economics 115: 18-36.

Core, J., W. Guay, and D. Larcker. 2008. The Power of the Pen and Executive Compensation. Journal of Financial Economics 88 (1): 1-25.

Cowle, E. N. and S. P. Rowe. 2019. Don't Make Me Look Bad: How the Audit Market Penalizes Auditors for Doing Their Job. Available at: https://papers.ssrn.com/sol3/papers.cfm?abstract_id=3228321

DeAngelo, L. E. 1981. Auditor Size and Audit Quality. Journal of Accounting and Economics 3 (3): 183199.

Dechow, P. M., R. G. Sloan, and A. P. Sweeney. 1995. Detecting Earnings Management. The Accounting Review 70 (2): 193-225.

DeFond, M., and C. Lennox. 2017. Do PCAOB Inspections Improve the Quality of Internal Control Audits. Journal of Accounting Research 55 (3): 591-627.

DeFond, M. and J. Zhang. 2014. A Review of Archival Auditing Research. Journal of Accounting and Economics 58: 275-326.

Dhaliwal, D. S.. and Q. Liu, and H. Xie, and J. Zhang, 2017 Negative Press Coverage, Litigation Risk, and Audit Opinions in China. Working Paper. Available at: https://ssrn.com/abstract=2381696 or http://dx.doi.org/10.2139/ssrn.2381696

Diermier, D., R. J. Crawford and C. Snyder. 2005. Arthur Andersen: The Collapse of Arthur Andersen. Kellogg School of Management. 
Doogar, R., S. Rowe, and P. Sivadasan. 2015. Asleep at the Wheel Again? Bank Audits during the Financial Crisis. Contemporary Accounting Research 32 (1): 358-391.

Dyck, A., N. Volchkova, and L. Zingales. 2008. The Corporate Governance Role of the Media: Evidence from Russia. Journal of Finance 63: 1093-1135.

Engelberg, J., and C. A. Parsons. 2011. The Causal Impact of Media in Financial Markets. Journal of Finance 66: 67-97.

Ertimur, Y., F. Ferri, and D.A. Maber. 2012. Reputation Penalties for Poor Monitoring of Executive Pay: Evidence from Option Backdating. Journal of Financial Economics 104 (1): 118-144.

Forelle, C., and J. Bandler. 2006. The Perfect Payday. Wall Street Journal. Accessed from: https://www.wsj.com/articles/SB114265075068802118

Francis, J. R. 2011. A Framework for Understanding and Researching Audit Quality. Auditing: A Journal of Practice and Theory 30 (2): 125-52.

Franklin, B., M. Hamer, M. Hanna, M. Kinsey and J. E. Richardson. 2005. Key Concepts in Journalism. London: SAGE.

Frost, C. 1991. Loss Contingency Reports and Stock Prices: A Replication and Extension of Banks and Kinney. Journal of Accounting Research 29 (1): 157-169.

Gipper, B., C. Leuz, M. Maffett and A. Karolyi. 2020. Public Oversight and Reporting Credibility: Evidence from the PCAOB Audit Inspection Regime. The Review of Financial Studies 33 (10): 4532-4579.

Gong, S. X., F. A. Gul, and L. Shan. 2018. Do Auditors Respond to Media Coverage? Evidence from China. Accounting Horizons 32 (3): 169-194.

Government Accountability Office (GAO). 2003. GAO Strategic Plan 2004-2009. Washington, D.C.: United States General Accounting Office. Available at: https://www.gao.gov/dsp/SPDraft.pdf

Hanlon, M. and N. Shroff. 2020. Insights into Auditor Public Oversight Boards: Whether, How, and Why they 'Work'. Working Paper. Available at: https://ssrn.com/abstract=3527584 or http://dx.doi.org/10.2139/ssrn.3527584

Hillert, A., H. Jacobs, and S. Müller. 2014. Media Makes Momentum. Review of Financial Studies 27: $3467-3501$.

Hirshleifer, D., S. S. Lim, and S. H. Teoh. 2009. Driven to Distraction: Extraneous Events and Underreaction to Earnings News. Journal of Finance 64: 2289-2325.

Joe, J. R. 2003. Why Press Coverage of a Client Influences the Audit Opinion. Journal of Accounting Research 41 (1): 109-133.

Joe, J., H. Louis, and D. Robinson. 2009. Managers' and Investors' Responses to Media Exposure of Board Ineffectiveness. Journal of Financial and Quantitative Analysis 44 (3): 579-605. 
Jones, J. J. 1991. Earnings Management during Import Relief Investigations. Journal of Accounting Research 29 (2): 193-228.

Kaplan, S. E., and D. D. Williams. 2013. Do Going Concern Audit Reports Protect Auditors from Litigation? A Simultaneous Equations Approach. The Accounting Review 88 (1): 199-232.

Kalogeropoulos, A., Svensson, H. M., van Dalen, A., de Vreese, C., and Albæk, E. 2015. Are Watchdogs Doing Their Business? Media Coverage of Economic News. Journalism 16 (8): 993-1009.

Kowsmann, P., M. Maurer and J. Yang. 2020. String of Firms That Imploded Have Something in Common: Ernst \& Young Audited Them. Wall Street Journal. Accessed from: https://www.wsj.com/articles/string-of-firms-that-imploded-have-something-in-common-ernstyoung-audited-them-11602863319

Krishnan, J., and J. Krishnan. 1997. Litigation Risk and Auditor Resignations. The Accounting Review 72 (4): 539-560.

Krishnan, J., J. Krishnan and H. Song. 2017. PCAOB International Inspections and Audit Quality. The Accounting Review 92 (5): 143-166.

Lamoreaux, P. T. 2016. Does PCAOB Inspection Access Improve Audit Quality? An Examination of Foreign Firms Listed in the United States. Journal of Accounting and Economics 61: 313-337.

Lie, E. 2005. On the Timing of CEO Stock Option Awards. Management Science 51 (5): 802-812.

Liu, B. and J. J. McConnell. 2013. The Role of the Media in Corporate Governance: Do the Media Influence Managers' Capital Allocation Decisions? Journal of Financial Economics 110: 1-17.

Miller, G. 2006. The Press as a Watchdog for Accounting Fraud. Journal of Accounting Research 44 (5): 1001-1033.

Miller, G., and D. Skinner. 2015. The Evolving Disclosure Landscape: How Changes in Technology, the Media, and Capital Markets are Affecting Disclosure. Journal of Accounting Research 53 (2): 221-239.

Nagy, A. 2014. PCAOB Quality Control Inspection Reports and Auditor Reputation. Auditing: A Journal of Practice and Theory 33 (3): 87-104.

Pratt, J., and J. Stice. 1994. The Effects of Client Characteristics on Auditor Litigation Risk Judgments, Required Audit Evidence, and Recommended Audit Fees. The Accounting Review 69 (4): 639656.

Public Accounting Report (PAR). 2002. Enron Debacle Creates Media Frenzy. January 31, 3.

Rawson, C. 2019. Overconfidence and Proprietary Investment Disclosure. Available at: https://ssrn.com/abstract=3215395

Schmidt, J. 2012. Perceived Auditor Independence and Audit Litigation: The Role of Nonaudit Services Fees. The Accounting Review 87 (3): 1033-1065. 
Shipman, J.E., Q. T. Swanquist, and R. L. Whited. 2017. Propensity Score Matching in Accounting Research. The Accounting Review 92 (1): 213-244

Simunic, D. A. and M. T. Stein. 1996. Impact of Litigation Risk on Audit Pricing: A Review of the Economics and the Evidence. Auditing: A Journal of Practice and Theory 15: 119-134.

Skinner, D. J., and S. Srinivasan. 2012. Audit Quality and Auditor Reputation: Evidence from Japan. The Accounting Review 87 (5): 1737-1765.

Smith, R., and J. R. Emshwiller. 2001a. Enron Says Its Links to a Partnership Led to \$1.2 Billion Equity Reduction. Wall Street Journal. Accessed from: https://www.wsj.com/articles/SB100336768216699600

Smith, R., and J. R. Emshwiller. 2001b. Enron CFO's Tie to a Partnership Resulted in Big Profits for the Firm. Wall Street Journal. Accessed from: https://www.wsj.com/articles/SB1003440729341052800

Smith, R., and J. R. Emshwiller. 2001c. Enron Faces Collapse as Dynegy Bolts and Stock Price, Credit Standing Dive. Wall Street Journal. Accessed from: https://www.wsj.com/articles/SB1006963515929275680

Smith, R., and J. R. Emshwiller. 2001d. Behind Enron's Fall, a Culture of Secrecy Which Cost the Firm Its Investors' Trust. Wall Street Journal. Accessed from: https://www.wsj.com/articles/SB1007502843500372680

Smith, R., and J. R. Emshwiller. 2009. 24 Days: How Two Wall Street Journal Reporters Uncovered the Lies that Destroyed Faith in Corporate America. Harper Collins.

Steiger, P. E. 2002. Not Every Journalist 'Missed' the Enron Story. Nieman Reports. Available at: https://niemanreports.org/articles/not-every-journalist-missed-the-enron-story/

Tetlock, P. C. 2007. Giving Content to Investor Sentiment: The Role of Media in the Stock Market. Journal of Finance 62:1139-68.

Weber, J., M. Willenborg, and J. Zhang. 2008. Does Auditor Reputation Matter? The Case of KPMG Germany and ComROAD AG. Journal of Accounting Research 46 (4): 941-972.

Westermann, K. D., J. Cohen, and G. Trompeter. 2018. PCAOB Inspections: Public Accounting Firms on "Trial." Contemporary Accounting Research 36 (2): 694-731. 


\section{Appendix 1: Variable Definitions}

\begin{tabular}{|c|c|}
\hline \multicolumn{2}{|l|}{ Dependent Variables } \\
\hline FEES & Equal to the natural logarithm of one plus the audit fees. \\
\hline DELAY & $\begin{array}{l}\text { The number of days between the fiscal year-end and the audit } \\
\text { opinion date. }\end{array}$ \\
\hline LATE & $\begin{array}{l}\text { Indicator variable set equal to one if the client files their financial } \\
\text { report after the SEC deadline, and zero otherwise. }\end{array}$ \\
\hline$A B S \_A C C$ & $\begin{array}{l}\text { The absolute value of abnormal accruals calculated using the } \\
\text { modified performance-adjusted version of the Jones (1991) model } \\
\text { (Dechow et al. 1995). }\end{array}$ \\
\hline MISSTATE_ $8 K$ & $\begin{array}{l}\text { Indicator variable set equal to one if the client has a financial } \\
\text { statement misstatement reported through a Form 8-K filing with } \\
\text { the SEC (as reported by Audit Analytics), and zero otherwise. }\end{array}$ \\
\hline INCOMING_CLIENT & $\begin{array}{l}\text { Indicator variable set equal to one if the client is new to its audit } \\
\text { firm, and zero otherwise. }\end{array}$ \\
\hline OUTGOING_CLIENT & $\begin{array}{l}\text { Indicator variable set equal to one if the client leaves its audit } \\
\text { firm, and zero otherwise. }\end{array}$ \\
\hline OVERALL_FIRM_GROWH & $\begin{array}{l}\text { Equal to the number of clients in the current year less the number } \\
\text { of clients in the previous year, divided by the number of clients in } \\
\text { the previous year. }\end{array}$ \\
\hline \multicolumn{2}{|l|}{ Variables of Interest } \\
\hline$\% N E G A T I V E \_N E W S$ & $\begin{array}{l}\text { Equal to the sum of the number of negative news articles about } \\
\text { the audit firm in the } 12 \text { months preceding the filing date of the } \\
\text { individual client's financial statements divided by the total } \\
\text { number of news articles about the audit firm over that same } \\
\text { period. }\end{array}$ \\
\hline$\% O T H E R \_N E W S$ & $\begin{array}{l}\text { The sum of the number of news articles about the audit firm that } \\
\text { reference audit but do not refer to financial statement } \\
\text { restatements, adverse ICOs and fraud in the } 12 \text { months preceding } \\
\text { the date of the individual client's financial statements divided by } \\
\text { the total number of news articles about the audit firm over that } \\
\text { same period. }\end{array}$ \\
\hline$\% R E S T A T E M E N T \_N E W S$ & $\begin{array}{l}\text { Equal to the number of news articles about the audit firm that } \\
\text { reference a restatement in the } 12 \text { months preceding the date of the } \\
\text { individual client's financial statements divided by the total } \\
\text { number of news articles about the audit firm over that same } \\
\text { period. }\end{array}$ \\
\hline$\% A I C O \_N E W S$ & $\begin{array}{l}\text { Equal to the number of news articles about the audit firm that } \\
\text { reference an adverse ICO in the } 12 \text { months preceding the date of } \\
\text { the individual client's financial statements divided by the total } \\
\text { number of news articles about the audit firm over that same } \\
\text { period. }\end{array}$ \\
\hline$\% F R A U D \_N E W S$ & $\begin{array}{l}\text { Equal to the number of news articles about the audit firm that } \\
\text { reference fraud in the } 12 \text { months preceding the date of the } \\
\text { individual client's financial statements divided by the total } \\
\text { number of news articles about the audit firm over that same } \\
\text { period. }\end{array}$ \\
\hline$\% N E G A T I V E \_N E W S \_P E E R$ & $\begin{array}{l}\text { Equal to the highest amount of } \% N E G A T I V E \_N E W S \text { received by } \\
\text { a peer firm during that period. }\end{array}$ \\
\hline
\end{tabular}




\begin{tabular}{|l|l|}
\hline$\% R E S T A T E M E N T \_N E W S \_P E E R$ & $\begin{array}{l}\text { Equal to the highest amount of RESTATEMENT_NEWS received } \\
\text { by a peer firm during that period. }\end{array}$ \\
\hline$\% A I C O \_N E W S \_P E E R$ & $\begin{array}{l}\text { Equal to the highest amount of } A I C O \_N E W S \text { received by a peer } \\
\text { firm during that period. }\end{array}$ \\
\hline
\end{tabular}

\begin{tabular}{|c|c|}
\hline \multicolumn{2}{|l|}{ Control Variables } \\
\hline SIZE & Equal to the natural logarithm of one plus total assets. \\
\hline$R O A$ & $\begin{array}{l}\text { Income before extraordinary items divided by beginning of year } \\
\text { total assets. }\end{array}$ \\
\hline LOSS & $\begin{array}{l}\text { Indicator variable set equal to one if net income is less than zero, } \\
\text { and zero otherwise. }\end{array}$ \\
\hline$I N V \_R E C$ & Equal to accounts receivable and inventory scaled by total assets. \\
\hline LEVERAGE & Total liabilities divided by total assets. \\
\hline BUSY & $\begin{array}{l}\text { Indicator variable set equal to one if the client's fiscal year-end is } \\
\text { in November, December, or January, and zero otherwise. }\end{array}$ \\
\hline INTANGIBLES & Intangible assets divided by total assets. \\
\hline AFILER & $\begin{array}{l}\text { Indicator variable set equal to one if the client is subject to the } \\
\text { reporting requirements of SOX } 404 \text { (b), and zero otherwise. }\end{array}$ \\
\hline AFILER_LARGE & $\begin{array}{l}\text { Indicator variable set equal to one if the client is subject to the } \\
\text { reporting requirements of SOX 404(b) for large accelerated filers, } \\
\text { and zero otherwise. }\end{array}$ \\
\hline FOR_OPS & $\begin{array}{l}\text { Indicator variable set equal to one if the client reports a currency } \\
\text { translation adjustment after net income to arrive at total } \\
\text { comprehensive income, and zero otherwise. }\end{array}$ \\
\hline EXCHANGE & $\begin{array}{l}\text { Indicator variable set equal to one if the client trades on a major } \\
\text { exchange (NYSE, American, NASDAQ), and zero otherwise. }\end{array}$ \\
\hline$I P O$ & $\begin{array}{l}\text { Indicator variable set equal to one if the client reports an initial } \\
\text { public offering, and zero otherwise. }\end{array}$ \\
\hline ACQUISITIONS & $\begin{array}{l}\text { Indicator variable set equal to one if the client reports an } \\
\text { acquisition, and zero otherwise. }\end{array}$ \\
\hline TENURE & $\begin{array}{l}\text { Indicator variable set equal to one if the current auditor's tenure is } \\
\text { more than four years, and zero otherwise. }\end{array}$ \\
\hline$A U D \_S I Z E$ & $\begin{array}{l}\text { Equal to the natural logarithm of one plus the number of unique } \\
\text { clients engaged by a firm in a given year. }\end{array}$ \\
\hline INFLUENCE & $\begin{array}{l}\text { Indicator variable set equal to one if the client's ratio of audit fees } \\
\text { to total audit fees collected by an office is above the median } \\
\text { value, and zero otherwise. }\end{array}$ \\
\hline RES_ANNOUNCE & $\begin{array}{l}\text { Indicator variable set equal to one if the prior period financial } \\
\text { statements are restated in that year, and zero otherwise. }\end{array}$ \\
\hline FIRM_RES_ANNOUNCE & $\begin{array}{l}\text { The number of audit firm clients with a RES_ANNOUNCE } \\
\text { divided by the total number of audit firm clients. }\end{array}$ \\
\hline$G C O$ & $\begin{array}{l}\text { Indicator variable set equal to one if the client receives a going } \\
\text { concern opinion, and zero otherwise. }\end{array}$ \\
\hline$A I C O$ & $\begin{array}{l}\text { Indicator variable set equal to one if the client receives an adverse } \\
\text { ICO and zero otherwise. }\end{array}$ \\
\hline
\end{tabular}




\section{Appendix 2: News Coverage Composition}

To create our sample of news coverage, we utilize Factiva and search for articles in major business news sources. Specifically, we search for articles in the Wall Street Journal, New York Times, Washington Post, Chicago Tribune, Forbes, The Economist, Economic Times, Kiplinger, Accounting Today, Wired, and CFO Magazine. These sources were determined by both their availability in Factiva and their widespread coverage of major business news.

For each of the Big 4, we require the presence of the firm name in the article. We note that with the exception of KPMG, abbreviated reference of the firm (e.g., E\&Y or PwC) always comes after referencing the firm by its official name since the firms use their full names for marketing and promotional purposes. Since KPMG rarely utilizes its full name (Klynveld Peat Marwick Goerdeler) in their own materials, news articles also rarely refer to the firm by its full name.

For audit specific news coverage, we require the presence of at least one "audit*" word where the * represents a wildcard that can be a space or any character. We do this to capture any audit related derivative word such as "auditing" or "auditor." We highlight the search terms for each category of negative news and tabulate the corresponding article counts below.

\begin{tabular}{|c|c|c|c|c|}
\hline $\begin{array}{l}\text { Firm } \\
\text { Name(s) } \\
\text { Searched } \\
\end{array}$ & 'Deloitte' & $\begin{array}{l}\text { 'Ernst \& Young', } \\
\text { 'Ernst and Young', }\end{array}$ & 'KPMG' & $\begin{array}{l}\text { 'Pricewaterhouse' } \\
\text { 'Pricewaterhouse } \\
\text { Coopers' }\end{array}$ \\
\hline \multicolumn{5}{|c|}{ Total News Coverage: } \\
\hline & 9,678 & 7,549 & 9,277 & 7,714 \\
\hline \multicolumn{5}{|c|}{ Audit News Coverage: } \\
\hline 'audit*' & 3,104 & 2,110 & 3,046 & 2,232 \\
\hline \multicolumn{5}{|c|}{ Negative Audit News Coverage: } \\
\hline $\begin{array}{l}\text { Restatement: } \\
\text { 'restat*' } \\
\text { 'misstat*' }\end{array}$ & 278 & 224 & 346 & 284 \\
\hline $\begin{array}{l}\text { ICO: } \\
\text { 'weaknes*' } \\
\text { 'contro*' }\end{array}$ & 101 & 110 & 101 & 139 \\
\hline $\begin{array}{l}\text { Fraud: } \\
\text { 'fraud' }\end{array}$ & 709 & 535 & 770 & 656 \\
\hline
\end{tabular}




\section{Figure 1: Auditor News Coverage Over Time}

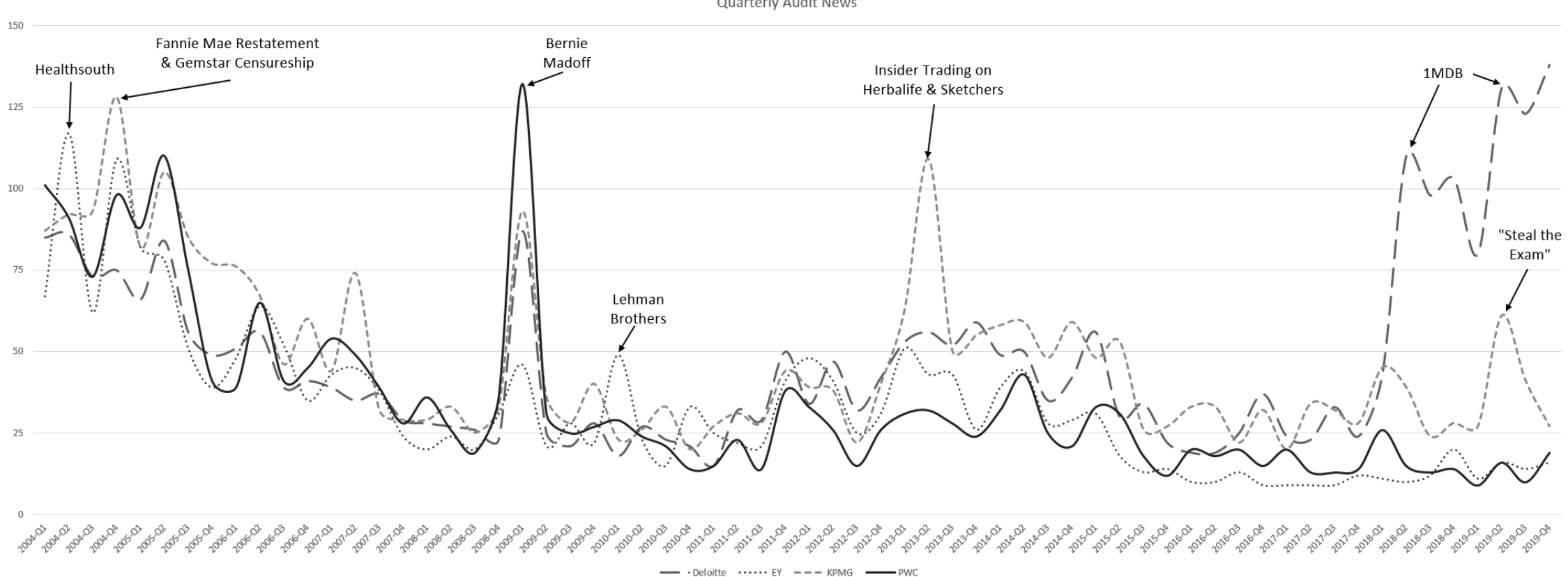




\section{Table 1: Auditor News Descriptive Statistics}

Table 1 presents the number of articles by audit firm for each calendar-year. Articles are classified as "Negative" news, which includes articles related to restatements, adverse ICOs and fraud. "Other" includes audit related news articles that do not reference one of the specific topics identified above.

\begin{tabular}{|c|c|c|c|c|c|c|c|c|c|c|c|c|}
\hline \multirow[t]{2}{*}{ Year } & \multicolumn{3}{|c|}{ Deloitte } & \multicolumn{3}{|c|}{ KPMG } & \multicolumn{3}{|c|}{ PwC } & \multicolumn{3}{|c|}{ Ernst \& Young } \\
\hline & $\begin{array}{l}\text { Non- } \\
\text { Audit }\end{array}$ & $\begin{array}{c}\text { Audit- } \\
\text { Negative }\end{array}$ & $\begin{array}{c}\text { Audit - } \\
\text { Other }\end{array}$ & $\begin{array}{l}\text { Non- } \\
\text { Audit }\end{array}$ & $\begin{array}{c}\text { Audit- } \\
\text { Negative }\end{array}$ & $\begin{array}{c}\text { Audit - } \\
\text { Other }\end{array}$ & $\begin{array}{l}\text { Non- } \\
\text { Audit }\end{array}$ & $\begin{array}{c}\text { Audit- } \\
\text { Negative }\end{array}$ & $\begin{array}{c}\text { Audit - } \\
\text { Other }\end{array}$ & $\begin{array}{l}\text { Non- } \\
\text { Audit }\end{array}$ & $\begin{array}{c}\text { Audit- } \\
\text { Negative }\end{array}$ & $\begin{array}{c}\text { Audit- } \\
\text { Other }\end{array}$ \\
\hline 2004 & 292 & 196 & 123 & 273 & 208 & 192 & 443 & 187 & 176 & 439 & 171 & 184 \\
\hline 2005 & 282 & 144 & 111 & 312 & 190 & 159 & 415 & 220 & 94 & 372 & 146 & 104 \\
\hline 2006 & 296 & 106 & 81 & 448 & 130 & 119 & 530 & 88 & 102 & 417 & 85 & 114 \\
\hline 2007 & 310 & 56 & 84 & 434 & 79 & 100 & 458 & 84 & 86 & 438 & 66 & 84 \\
\hline 2008 & 334 & 32 & 72 & 399 & 31 & 89 & 444 & 57 & 60 & 425 & 31 & 64 \\
\hline 2009 & 377 & 86 & 75 & 443 & 113 & 84 & 383 & 135 & 80 & 447 & 36 & 81 \\
\hline 2010 & 307 & 25 & 64 & 425 & 29 & 73 & 350 & 40 & 48 & 444 & 40 & 80 \\
\hline 2011 & 378 & 40 & 86 & 384 & 40 & 90 & 292 & 44 & 46 & 442 & 41 & 68 \\
\hline 2012 & 458 & 65 & 90 & 429 & 53 & 86 & 346 & 36 & 64 & 525 & 65 & 80 \\
\hline 2013 & 564 & 62 & 158 & 451 & 87 & 190 & 413 & 48 & 67 & 427 & 56 & 107 \\
\hline 2014 & 490 & 58 & 118 & 428 & 63 & 161 & 363 & 39 & 82 & 266 & 46 & 94 \\
\hline 2015 & 485 & 40 & 102 & 449 & 39 & 115 & 316 & 25 & 69 & 247 & 31 & 45 \\
\hline 2016 & 473 & 21 & 79 & 407 & 13 & 107 & 259 & 20 & 53 & 151 & 15 & 27 \\
\hline 2017 & 548 & 10 & 94 & 378 & 17 & 97 & 210 & 9 & 51 & 139 & 8 & 31 \\
\hline 2018 & 489 & 57 & 297 & 322 & 49 & 87 & 148 & 21 & 47 & 137 & 19 & 34 \\
\hline 2019 & 491 & 90 & 382 & 249 & 76 & 80 & 112 & 26 & 28 & 123 & 13 & 44 \\
\hline Total & 6,574 & 1,088 & 2,016 & 6,231 & 1,217 & 1,829 & 5,482 & 1,079 & 1,153 & 5,439 & 869 & 1,241 \\
\hline
\end{tabular}


Table 2: Descriptive Statistics

Table 2 presents the descriptive statistics for the full sample of client-year observations. Variable definitions are provided in Appendix 1.

\begin{tabular}{|c|c|c|c|c|c|c|}
\hline Variable & $\mathbf{N}$ & Mean & SD & p25 & p50 & p75 \\
\hline FEES & 22,873 & 14.260 & 0.989 & 13.581 & 14.194 & 14.901 \\
\hline$D E L A Y$ & 22,873 & 61.950 & 17.290 & 54.000 & 59.000 & 69.000 \\
\hline LATE & 22,873 & 0.057 & 0.231 & 0.000 & 0.000 & 0.000 \\
\hline$A B S \_A C C$ & 22,873 & 0.056 & 0.062 & 0.016 & 0.036 & 0.071 \\
\hline MISSTATE_ $8 K$ & 22,873 & 0.022 & 0.147 & 0.000 & 0.000 & 0.000 \\
\hline$\% N E G A T I V E \_N E W S$ & 22,873 & 0.093 & 0.041 & 0.065 & 0.091 & 0.112 \\
\hline$\% O T H E R \_N E W S$ & 22,873 & 0.163 & 0.040 & 0.139 & 0.160 & 0.181 \\
\hline \%RESTATEMENT_NEWS & 22,873 & 0.021 & 0.017 & 0.010 & 0.015 & 0.023 \\
\hline$\% A I C O \_N E W S$ & 22,873 & 0.008 & 0.008 & 0.002 & 0.006 & 0.012 \\
\hline$\% F R A U D \_N E W S$ & 22,873 & 0.064 & 0.027 & 0.053 & 0.059 & 0.076 \\
\hline SIZE & 22,873 & 6.910 & 1.776 & 5.701 & 6.915 & 8.092 \\
\hline$R O A$ & 22,873 & -0.025 & 0.245 & -0.036 & 0.038 & 0.083 \\
\hline LOSS & 22,873 & 0.328 & 0.469 & 0.000 & 0.000 & 1.000 \\
\hline$I N V \_R E C$ & 22,873 & 0.233 & 0.172 & 0.097 & 0.209 & 0.331 \\
\hline$L E V E R A G E$ & 22,873 & 0.546 & 0.299 & 0.345 & 0.521 & 0.688 \\
\hline$B U S Y$ & 22,873 & 0.781 & 0.414 & 1.000 & 1.000 & 1.000 \\
\hline INTANGIBLES & 22,873 & 0.205 & 0.209 & 0.019 & 0.138 & 0.338 \\
\hline AFILER & 22,873 & 0.341 & 0.474 & 0.000 & 0.000 & 1.000 \\
\hline AFILER_LARGE & 22,873 & 0.541 & 0.498 & 0.000 & 1.000 & 1.000 \\
\hline FOR_OPS & 22,873 & 0.654 & 0.476 & 0.000 & 1.000 & 1.000 \\
\hline EXCHANGE & 22,873 & 0.914 & 0.280 & 1.000 & 1.000 & 1.000 \\
\hline$I P O$ & 22,873 & 0.013 & 0.114 & 0.000 & 0.000 & 0.000 \\
\hline ACQUISITIONS & 22,873 & 0.436 & 0.496 & 0.000 & 0.000 & 1.000 \\
\hline TENURE & 22,873 & 0.865 & 0.341 & 1.000 & 1.000 & 1.000 \\
\hline$A U D \_S I Z E$ & 22,873 & 7.379 & 0.198 & 7.265 & 7.406 & 7.516 \\
\hline$G C O$ & 22,873 & 0.028 & 0.165 & 0.000 & 0.000 & 0.000 \\
\hline FIRM_RES_ANNOUNCE & 22,873 & 0.025 & 0.010 & 0.017 & 0.023 & 0.030 \\
\hline INFLUENCE & 22,873 & 0.490 & 0.500 & 0.000 & 0.000 & 1.000 \\
\hline$A I C O$ & 22,873 & 0.035 & 0.185 & 0.000 & 0.000 & 0.000 \\
\hline RES_ANNOUNCE & 22,873 & 0.042 & 0.200 & 0.000 & 0.000 & 0.000 \\
\hline
\end{tabular}




\section{Table 3: Effect of Negative News Coverage on Audit Attention}

Table 3 presents the results of our OLS regression analysis of Equation (1). The dependent variables are measures of auditor attention determined by FEES, DELAY, and LATE. Our primary variable of interest is \%NEGATIVE_NEWS. All variables are formally defined in Appendix 1. Robust standard errors are clustered by company. $T$-statistics are presented in parentheses below the corresponding coefficients. ${ }^{*}, * *$, and $* * *$ indicate significance at the $0.10,0.05$, and 0.01 levels, respectively (based on two-tailed tests).

\begin{tabular}{|c|c|c|c|}
\hline & $\begin{array}{r}\text { FEES } \\
(1) \\
\end{array}$ & $\begin{array}{r}\text { DELAY } \\
(2) \\
\end{array}$ & $\begin{array}{r}\text { LATE } \\
(3) \\
\end{array}$ \\
\hline$\overline{\% N E G A T I V E \_N E W S}$ & $\begin{array}{l}0.684 * * * \\
(5.96)\end{array}$ & $\begin{array}{l}13.930 * * * \\
(3.42)\end{array}$ & $\begin{array}{l}0.188 * * * \\
(3.35)\end{array}$ \\
\hline SIZE & $\begin{array}{l}0.408 * * * \\
(49.86)\end{array}$ & $\begin{array}{l}-2.016 * * * \\
(-14.09)\end{array}$ & $\begin{array}{l}-0.008 * * * \\
(-4.72)\end{array}$ \\
\hline$R O A$ & $\begin{array}{l}-0.207 * * * \\
(-6.31)\end{array}$ & $\begin{array}{l}-0.920 \\
(-1.36)\end{array}$ & $\begin{array}{r}0.009 \\
(0.71)\end{array}$ \\
\hline LOSS & $\begin{array}{l}0.086 \text { *** } \\
(6.62)\end{array}$ & $\begin{array}{l}1.365 * * * \\
(4.25)\end{array}$ & $\begin{array}{l}0.032 \text { *** } \\
(6.47)\end{array}$ \\
\hline$I N V \_R E C$ & $\begin{array}{l}0.589 * * * \\
(9.80)\end{array}$ & $\begin{array}{l}1.918 \\
(1.58)\end{array}$ & $\begin{array}{l}0.052 * * * \\
(3.63)\end{array}$ \\
\hline LEVERAGE & $\begin{array}{l}0.196^{* * *} \\
(7.93)\end{array}$ & $\begin{array}{l}0.437 \\
(0.79)\end{array}$ & $\begin{array}{r}0.012 \\
(1.49)\end{array}$ \\
\hline$B U S Y$ & $\begin{array}{l}0.051 * * * \\
(2.84)\end{array}$ & $\begin{array}{l}0.603 * \\
(1.65)\end{array}$ & $\begin{array}{l}-0.000 \\
(-0.11)\end{array}$ \\
\hline INTANGIBLES & $\begin{array}{c}0.014 \\
(0.36)\end{array}$ & $\begin{array}{l}3.040 * * * \\
(3.86)\end{array}$ & $\begin{array}{l}0.007 \\
(0.69)\end{array}$ \\
\hline AFILER & $\begin{array}{l}0.120 * * * \\
(5.52)\end{array}$ & $\begin{array}{l}-7.765 * * * \\
(-12.58)\end{array}$ & $\begin{array}{l}-0.014 * \\
(-1.69)\end{array}$ \\
\hline AFILER_LARGE & $\begin{array}{c}0.044 \\
(1.64)\end{array}$ & $\begin{array}{l}-15.462 * * * \\
(-22.16)\end{array}$ & $\begin{array}{l}-0.018 * * \\
(-2.01)\end{array}$ \\
\hline FOR_OPS & $\begin{array}{l}0.181 \text { *** } \\
(10.98)\end{array}$ & $\begin{array}{l}0.714 * * \\
(2.06)\end{array}$ & $\begin{array}{l}0.016 \text { *** } \\
(3.47)\end{array}$ \\
\hline EXCHANGE & $\begin{array}{l}0.072 * * * \\
(2.72)\end{array}$ & $\begin{array}{l}-2.790 * * * \\
(-3.67)\end{array}$ & $\begin{array}{l}-0.051 * * * \\
(-4.77)\end{array}$ \\
\hline$I P O$ & $\begin{array}{l}0.252 * * * \\
(7.19)\end{array}$ & $\begin{array}{l}-3.839 * * * \\
(-4.24)\end{array}$ & $\begin{array}{l}-0.042 * * * \\
(-3.64)\end{array}$ \\
\hline ACQUISITIONS & $\begin{array}{l}0.044 * * * \\
(4.09)\end{array}$ & $\begin{array}{l}0.531 * * \\
(2.15)\end{array}$ & $\begin{array}{r}0.003 \\
(0.84)\end{array}$ \\
\hline TENURE & $\begin{array}{l}0.039^{* * * *} \\
(3.17)\end{array}$ & $\begin{array}{l}-1.303 * * * \\
(-3.44)\end{array}$ & $\begin{array}{l}-0.017 * * * \\
(-3.15)\end{array}$ \\
\hline$A U D \_S I Z E$ & $\begin{array}{l}0.203 * * * \\
(3.96)\end{array}$ & $\begin{array}{l}-3.526 * * * \\
(-3.52)\end{array}$ & $\begin{array}{l}-0.031 * * \\
(-2.43)\end{array}$ \\
\hline$G C O$ & $\begin{array}{l}0.131 \text { *** } \\
(4.55)\end{array}$ & $\begin{array}{l}6.114 * * * \\
(6.03)\end{array}$ & $\begin{array}{l}0.165 * * * \\
(8.45)\end{array}$ \\
\hline FIRM_RES_ANNOUNCE & $\begin{array}{l}3.710 * * * \\
(6.35)\end{array}$ & $\begin{array}{c}37.667 * * \\
(2.09)\end{array}$ & $\begin{array}{l}0.847 * * * \\
(3.21)\end{array}$ \\
\hline INFLUENCE & $\begin{array}{l}0.442 * * * \\
(27.46)\end{array}$ & $\begin{array}{l}2.003 * * * \\
(6.23)\end{array}$ & $\begin{array}{l}0.024 * * * \\
(5.80)\end{array}$ \\
\hline$A I C O$ & $\begin{array}{l}0.331 * * * \\
(15.48)\end{array}$ & $\begin{array}{l}23.567 * * * \\
(13.71)\end{array}$ & $\begin{array}{l}0.408 * * * \\
(22.37)\end{array}$ \\
\hline RES_ANNOUNCE & $\begin{array}{l}0.057 * * * \\
(4.06)\end{array}$ & $\begin{array}{l}6.501 * * * \\
(5.98)\end{array}$ & $\begin{array}{l}0.123 \text { *** } \\
(10.50)\end{array}$ \\
\hline $\begin{array}{l}\text { Year FE } \\
\text { Industry FE }\end{array}$ & $\begin{array}{l}\text { Yes } \\
\text { Yes }\end{array}$ & $\begin{array}{l}\text { Yes } \\
\text { Yes }\end{array}$ & $\begin{array}{l}\text { Yes } \\
\text { Yes }\end{array}$ \\
\hline $\begin{array}{l}\text { Adj } R^{2} \\
N\end{array}$ & $\begin{array}{r}0.819 \\
22,873\end{array}$ & $\begin{array}{r}0.347 \\
22,873\end{array}$ & $\begin{array}{r}0.200 \\
22,873\end{array}$ \\
\hline
\end{tabular}




\section{Table 4: Effect of Negative News Coverage on Audit Attention by Event Type}

Table 4 presents the results of our OLS regression analysis of Equation (1). The dependent variables are measures of auditor attention determined by FEES, DELAY and LATE. Our primary variable of interest is the interaction of $A I C O$ $x \% A I C O \_N E W S$ in Panel A and the interaction of RES_ANNOUNCE $x \% R E S T A T E M E N T \_N E W S$ in Panel B. All variables are formally defined in Appendix 1. Robust standard errors are clustered by company. $T$-statistics are presented in parentheses below the corresponding coefficients. $*$, **, and $* * *$ indicate significance at the $0.10,0.05$, and 0.01 levels, respectively (based on two-tailed tests).

Panel A: Adverse ICO and Adverse ICO News

\begin{tabular}{|c|c|c|c|}
\hline & $\begin{array}{r}\text { FEES } \\
(1) \\
\end{array}$ & $\begin{array}{r}\text { DELAY } \\
(2) \\
\end{array}$ & $\begin{array}{r}\text { LATE } \\
(3) \\
\end{array}$ \\
\hline$\% A I C O \_N E W S$ & $\begin{array}{l}2.551 * * * \\
(4.21)\end{array}$ & $\begin{array}{r}25.555 \\
(1.26)\end{array}$ & $\begin{array}{r}0.335 \\
(1.01)\end{array}$ \\
\hline$A I C O$ & $\begin{array}{l}0.292 * * * \\
(9.55)\end{array}$ & $\begin{array}{l}12.845 * * * \\
(4.91)\end{array}$ & $\begin{array}{l}0.333 * * * \\
(12.75)\end{array}$ \\
\hline AICOx \%AICO_NEWS & $\begin{array}{l}3.930 * \\
(1.82)\end{array}$ & $\begin{array}{c}1082.00 * * * \\
(3.96)\end{array}$ & $\begin{array}{l}7.514 * * * \\
(3.92)\end{array}$ \\
\hline SIZE & $\begin{array}{l}0.408 * * * \\
(49.84)\end{array}$ & $\begin{array}{l}-2.020 * * * \\
(-14.07)\end{array}$ & $\begin{array}{l}-0.008 * * * \\
(-4.72)\end{array}$ \\
\hline$R O A$ & $\begin{array}{l}-0.209 * * * \\
(-6.34)\end{array}$ & $\begin{array}{l}-0.954 \\
(-1.40)\end{array}$ & $\begin{array}{r}0.008 \\
(0.68)\end{array}$ \\
\hline LOSS & $\begin{array}{l}0.086 * * * \\
(6.62)\end{array}$ & $\begin{array}{l}1.384 * * * \\
(4.31)\end{array}$ & $\begin{array}{l}0.032 * * * \\
(6.50)\end{array}$ \\
\hline$I N V_{-} R E C$ & $\begin{array}{l}0.588 * * * \\
(9.78)\end{array}$ & $\begin{array}{l}2.077^{*} \\
(1.72)\end{array}$ & $\begin{array}{l}0.053 * * * \\
(3.70)\end{array}$ \\
\hline LEVERAGE & $\begin{array}{l}0.195 * * * \\
(7.89)\end{array}$ & $\begin{array}{r}0.474 \\
(0.85)\end{array}$ & $\begin{array}{l}0.012 \\
(1.50)\end{array}$ \\
\hline$B U S Y$ & $\begin{array}{l}0.051 * * * \\
(2.80)\end{array}$ & $\begin{array}{l}0.599 \\
(1.63)\end{array}$ & $\begin{array}{l}-0.001 \\
(-0.14)\end{array}$ \\
\hline INTANGIBLES & $\begin{array}{l}0.015 \\
(0.38)\end{array}$ & $\begin{array}{l}3.320 * * * \\
(4.26)\end{array}$ & $\begin{array}{r}0.009 \\
(0.89)\end{array}$ \\
\hline AFILER & $\begin{array}{l}0.120 * * * \\
(5.53)\end{array}$ & $\begin{array}{l}-7.786 \text { *** } \\
(-12.56)\end{array}$ & $\begin{array}{l}-0.014^{*} \\
(-1.70)\end{array}$ \\
\hline AFILER_LARGE & $\begin{array}{l}0.044^{*} \\
(1.65)\end{array}$ & $\begin{array}{l}-15.448 * * * \\
(-22.05)\end{array}$ & $\begin{array}{l}-0.018 * * \\
(-1.98)\end{array}$ \\
\hline FOR_OPS & $\begin{array}{l}0.181 \text { *** } \\
(10.95)\end{array}$ & $\begin{array}{l}0.659 * \\
(1.90)\end{array}$ & $\begin{array}{l}0.015 * * * \\
(3.39)\end{array}$ \\
\hline EXCHANGE & $\begin{array}{l}0.072 * * * \\
(2.72)\end{array}$ & $\begin{array}{l}-2.697 * * * \\
(-3.51)\end{array}$ & $\begin{array}{l}-0.050 * * * \\
(-4.71)\end{array}$ \\
\hline$I P O$ & $\begin{array}{l}0.253 * * * \\
(7.23)\end{array}$ & $\begin{array}{l}-3.832 * * * \\
(-4.24)\end{array}$ & $\begin{array}{l}-0.042 * * * \\
(-3.62)\end{array}$ \\
\hline ACQUISITIONS & $\begin{array}{l}0.044 * * * \\
(4.08)\end{array}$ & $\begin{array}{l}0.540 * * \\
(2.19)\end{array}$ & $\begin{array}{r}0.003 \\
(0.86)\end{array}$ \\
\hline TENURE & $\begin{array}{l}0.039 * * * \\
(3.18)\end{array}$ & $\begin{array}{l}-1.340 * * * \\
(-3.53)\end{array}$ & $\begin{array}{l}-0.018 * * * \\
(-3.19)\end{array}$ \\
\hline$A U D \_S I Z E$ & $\begin{array}{l}0.172 * * * \\
(3.39)\end{array}$ & $\begin{array}{l}-4.138 * * * \\
(-4.12)\end{array}$ & $\begin{array}{l}-0.039 * * * \\
(-3.06)\end{array}$ \\
\hline$G C O$ & $\begin{array}{l}0.131 \text { *** } \\
(4.51)\end{array}$ & $\begin{array}{l}6.065 * * * \\
(5.90)\end{array}$ & $\begin{array}{l}0.165 * * * \\
(8.44)\end{array}$ \\
\hline FIRM_RES_ANNOUNCE & $\begin{array}{l}3.828 * * * \\
(6.47)\end{array}$ & $\begin{array}{c}34.718 * \\
(1.93)\end{array}$ & $\begin{array}{l}0.838 * * * \\
(3.16)\end{array}$ \\
\hline INFLUENCE & $\begin{array}{l}0.442 * * * \\
(27.43)\end{array}$ & $\begin{array}{l}1.918 * * * \\
(5.97)\end{array}$ & $\begin{array}{l}0.024 * * * \\
(5.64)\end{array}$ \\
\hline RES_ANNOUNCE & $\begin{array}{l}0.056 * * * \\
(3.97)\end{array}$ & $\begin{array}{l}6.337 * * * \\
(5.96)\end{array}$ & $\begin{array}{l}0.122 * * * \\
(10.40)\end{array}$ \\
\hline $\begin{array}{l}\text { Year FE } \\
\text { Industry FE }\end{array}$ & $\begin{array}{l}\text { Yes } \\
\text { Yes }\end{array}$ & $\begin{array}{l}\text { Yes } \\
\text { Yes }\end{array}$ & $\begin{array}{l}\text { Yes } \\
\text { Yes }\end{array}$ \\
\hline $\begin{array}{l}\text { Adj } R^{2} \\
N\end{array}$ & $\begin{array}{r}0.819 \\
22,873 \\
\end{array}$ & $\begin{array}{r}0.358 \\
22,873 \\
\end{array}$ & $\begin{array}{r}0.203 \\
22,873 \\
\end{array}$ \\
\hline
\end{tabular}


Panel B: Restatement Announcement of Prior Period Financials and Restatement News

\begin{tabular}{|c|c|c|c|}
\hline & $\begin{array}{r}\text { FEES } \\
(1) \\
\end{array}$ & $\begin{array}{r}\text { DELAY } \\
(2) \\
\end{array}$ & $\begin{array}{r}\text { LATE } \\
(3) \\
\end{array}$ \\
\hline$\%$ RESTATEMENT_NEWS & $\begin{array}{r}0.225 \\
(0.81)\end{array}$ & $\begin{array}{l}37.688 * * * \\
(3.19)\end{array}$ & $\begin{array}{l}0.425 * * * \\
(2.60)\end{array}$ \\
\hline RES_ANNOUNCE & $\begin{array}{l}0.034 \\
(1.50)\end{array}$ & $\begin{array}{l}-1.784 \\
(-0.97)\end{array}$ & $\begin{array}{l}0.035 * \\
(1.94)\end{array}$ \\
\hline RES_ANNOUNCEX $x$ \%RETATEMENT_NEWS & $\begin{array}{r}0.960 \\
(1.20)\end{array}$ & $\begin{array}{l}353.205 * * * \\
\quad(3.77)\end{array}$ & $\begin{array}{l}3.737 * * * \\
(5.39)\end{array}$ \\
\hline SIZE & $\begin{array}{l}0.409 * * * \\
(49.82)\end{array}$ & $\begin{array}{l}-2.002 * * * \\
(-13.89)\end{array}$ & $\begin{array}{l}-0.008 * * * \\
(-4.61)\end{array}$ \\
\hline$R O A$ & $\begin{array}{l}-0.209 * * * \\
(-6.33)\end{array}$ & $\begin{array}{l}-0.973 \\
(-1.44)\end{array}$ & $\begin{array}{r}0.008 \\
(0.66)\end{array}$ \\
\hline LOSS & $\begin{array}{l}0.086 * * * \\
(6.59)\end{array}$ & $\begin{array}{l}1.374 * * * \\
(4.31)\end{array}$ & $\begin{array}{l}0.032 * * * \\
(6.52)\end{array}$ \\
\hline$I N V_{-} R E C$ & $\begin{array}{l}0.588 * * * \\
(9.76)\end{array}$ & $\begin{array}{l}2.037 * \\
(1.68)\end{array}$ & $\begin{array}{l}0.053 * * * \\
(3.74)\end{array}$ \\
\hline LEVERAGE & $\begin{array}{l}0.195 * * * \\
(7.87)\end{array}$ & $\begin{array}{r}0.523 \\
(0.94)\end{array}$ & $\begin{array}{l}0.013 \\
(1.60)\end{array}$ \\
\hline BUSY & $\begin{array}{l}0.051 * * * \\
(2.80)\end{array}$ & $\begin{array}{l}0.616 * \\
(1.70)\end{array}$ & $\begin{array}{l}-0.000 \\
(-0.08)\end{array}$ \\
\hline INTANGIBLES & $\begin{array}{l}0.014 \\
(0.36)\end{array}$ & $\begin{array}{l}3.081 * * * \\
(3.91)\end{array}$ & $\begin{array}{r}0.007 \\
(0.74)\end{array}$ \\
\hline AFILER & $\begin{array}{l}0.120 * * * \\
(5.53)\end{array}$ & $\begin{array}{l}-7.751 * * * \\
(-12.61)\end{array}$ & $\begin{array}{l}-0.013 * \\
(-1.68)\end{array}$ \\
\hline AFILER_LARGE & $\begin{array}{l}0.045 * \\
(1.68)\end{array}$ & $\begin{array}{l}-15.403 * * * \\
(-22.11)\end{array}$ & $\begin{array}{l}-0.017 * \\
(-1.94)\end{array}$ \\
\hline FOR_OPS & $\begin{array}{l}0.181 * * * \\
(10.96)\end{array}$ & $\begin{array}{l}0.747 * * \\
(2.16)\end{array}$ & $\begin{array}{l}0.016 * * * \\
(3.57)\end{array}$ \\
\hline EXCHANGE & $\begin{array}{l}0.071 * * * \\
(2.67)\end{array}$ & $\begin{array}{l}-2.767 * * * \\
(-3.66)\end{array}$ & $\begin{array}{l}-0.050 * * * \\
(-4.77)\end{array}$ \\
\hline$I P O$ & $\begin{array}{l}0.253 * * * \\
(7.22)\end{array}$ & $\begin{array}{l}-3.899 * * * \\
(-4.28)\end{array}$ & $\begin{array}{l}-0.043 * * * \\
(-3.60)\end{array}$ \\
\hline ACQUISITIONS & $\begin{array}{l}0.044 * * * \\
(4.08)\end{array}$ & $\begin{array}{l}0.511 * * \\
(2.07)\end{array}$ & $\begin{array}{r}0.003 \\
(0.78)\end{array}$ \\
\hline TENURE & $\begin{array}{l}0.040 * * * \\
(3.19)\end{array}$ & $\begin{array}{l}-1.270 * * * \\
(-3.39)\end{array}$ & $\begin{array}{l}-0.017 * * * \\
(-3.10)\end{array}$ \\
\hline$A U D \_S I Z E$ & $\begin{array}{l}0.188 * * * \\
(3.69)\end{array}$ & $\begin{array}{l}-2.910 * * * \\
(-2.88)\end{array}$ & $\begin{array}{l}-0.025 * * \\
(-1.96)\end{array}$ \\
\hline$G C O$ & $\begin{array}{l}0.131 * * * \\
(4.51)\end{array}$ & $\begin{array}{l}6.212 * * * \\
(6.12)\end{array}$ & $\begin{array}{l}0.166 * * * \\
(8.49)\end{array}$ \\
\hline FIRM_RES_ANNOUNCE & $\begin{array}{l}3.638 * * * \\
(6.20)\end{array}$ & $\begin{array}{r}14.879 \\
(0.86)\end{array}$ & $\begin{array}{l}0.597 * * \\
(2.27)\end{array}$ \\
\hline INFLUENCE & $\begin{array}{l}0.441 * * * \\
(27.36)\end{array}$ & $\begin{array}{l}1.930 * * * \\
(6.03)\end{array}$ & $\begin{array}{l}0.023 * * * \\
(5.62)\end{array}$ \\
\hline$A I C O$ & $\begin{array}{l}0.332 * * * \\
(15.55)\end{array}$ & $\begin{array}{l}23.524 * * * \\
(13.80)\end{array}$ & $\begin{array}{l}0.407 * * * \\
(22.47)\end{array}$ \\
\hline $\begin{array}{l}\text { Year FE } \\
\text { Industry FE }\end{array}$ & $\begin{array}{c}\text { Yes } \\
\text { Yes }\end{array}$ & $\begin{array}{l}\text { Yes } \\
\text { Yes }\end{array}$ & $\begin{array}{c}\text { Yes } \\
\text { Yes } \\
\end{array}$ \\
\hline $\begin{array}{l}\operatorname{Adj} R^{2} \\
N\end{array}$ & $\begin{array}{r}0.819 \\
22,873 \\
\end{array}$ & $\begin{array}{r}0.354 \\
22,873\end{array}$ & $\begin{array}{r}0.204 \\
22,873 \\
\end{array}$ \\
\hline
\end{tabular}


Table 5: Effect of Other Audit News Coverage on Audit Attention

Table 5 presents the results of our OLS regression analysis of Equation (1). The dependent variables are measures of auditor attention determined by FEES, DELAY, and LATE. Our primary variable of interest is \%OTHER_NEWS. All variables are formally defined in Appendix 1. Robust standard errors are clustered by company. $T$-statistics are presented in parentheses below the corresponding coefficients. ${ }^{*}, * *$, and $* * *$ indicate significance at the $0.10,0.05$, and 0.01 levels, respectively (based on two-tailed tests).

\begin{tabular}{|c|c|c|c|}
\hline & $\begin{array}{r}\text { FEES } \\
(1) \\
\end{array}$ & $\begin{array}{r}\text { DELAY } \\
(2) \\
\end{array}$ & $\begin{array}{r}\text { LATE } \\
(3) \\
\end{array}$ \\
\hline \multirow[t]{2}{*}{ \%OTHER_NEWS } & $-0.674 * * *$ & $-7.768 * * *$ & -0.057 \\
\hline & $(-7.06)$ & $(-2.77)$ & $(-1.21)$ \\
\hline \multirow[t]{2}{*}{ SIZE } & $0.408 * * *$ & $-2.014 * * *$ & $-0.008 * * *$ \\
\hline & $(49.83)$ & $(-14.07)$ & $(-4.69)$ \\
\hline \multirow[t]{2}{*}{$R O A$} & $-0.208 * * *$ & -0.941 & 0.008 \\
\hline & $(-6.34)$ & $(-1.39)$ & $(0.69)$ \\
\hline \multirow[t]{2}{*}{$L O S S$} & $0.086^{* * *}$ & $1.362 * * *$ & $0.032 * * *$ \\
\hline & $(6.61)$ & $(4.24)$ & $(6.46)$ \\
\hline \multirow[t]{2}{*}{$I N V_{-} R E C$} & $0.588 * * *$ & 1.895 & $0.052 * * *$ \\
\hline & $(9.78)$ & $(1.56)$ & $(3.60)$ \\
\hline \multirow[t]{2}{*}{ LEVERAGE } & $0.195 * * *$ & 0.418 & 0.012 \\
\hline & $(7.90)$ & $(0.75)$ & $(1.45)$ \\
\hline \multirow[t]{2}{*}{ BUSY } & $0.051 * * *$ & 0.598 & -0.001 \\
\hline & $(2.85)$ & (1.64) & $(-0.15)$ \\
\hline \multirow{2}{*}{ INTANGIBLES } & 0.015 & $3.048 * * *$ & 0.007 \\
\hline & $(0.38)$ & $(3.87)$ & $(0.70)$ \\
\hline \multirow[t]{2}{*}{ AFILER } & $0.120 * * *$ & $-7.758 * * *$ & $-0.013 *$ \\
\hline & $(5.54)$ & $(-12.57)$ & $(-1.68)$ \\
\hline \multirow[t]{2}{*}{$A F I L E R \_L A R G E$} & $0.044 *$ & $-15.445 * * *$ & $-0.018 * *$ \\
\hline & $(1.65)$ & $(-22.16)$ & $(-1.98)$ \\
\hline \multirow[t]{2}{*}{ FOR_OPS } & $0.181 * * *$ & $0.708 * *$ & $0.016 * * *$ \\
\hline & (10.96) & $(2.04)$ & (3.46) \\
\hline \multirow[t]{2}{*}{ EXCHANGE } & $0.070 * * *$ & $-2.82 * * *$ & $-0.051 * * *$ \\
\hline & (2.66) & $(-3.72)$ & $(-4.81)$ \\
\hline \multirow[t]{2}{*}{$I P O$} & $0.254 * * *$ & $-3.793 * * *$ & $-0.042 * * *$ \\
\hline & $(7.27)$ & $(-4.20)$ & $(-3.59)$ \\
\hline \multirow[t]{2}{*}{ ACQUISITIONS } & $0.044 * * *$ & $0.528 * *$ & 0.003 \\
\hline & $(4.08)$ & $(2.14)$ & $(0.83)$ \\
\hline \multirow[t]{2}{*}{ TENURE } & $0.038 * * *$ & $-1.319 * * *$ & $-0.017 * * *$ \\
\hline & (3.05) & $(-3.48)$ & $(-3.16)$ \\
\hline \multirow[t]{2}{*}{$A U D \_S I Z E$} & $0.131 * * *$ & $-4.536 * * *$ & $-0.041 * * *$ \\
\hline & $(2.61)$ & $(-4.40)$ & $(-3.03)$ \\
\hline \multirow[t]{2}{*}{$G C O$} & $0.129 * * *$ & $6.076 * * *$ & $0.165 * * *$ \\
\hline & $(4.46)$ & (5.99) & $(8.43)$ \\
\hline \multirow[t]{2}{*}{ FIRM_RES_ANNOUNCE } & $3.722 * * *$ & $38.249 * *$ & $0.857 * * *$ \\
\hline & (6.39) & $(2.11)$ & $(3.25)$ \\
\hline \multirow[t]{2}{*}{ INFLUENCE } & $0.443 * * *$ & $1.996 * * *$ & $0.024 * * *$ \\
\hline & (27.45) & $(6.22)$ & $(5.77)$ \\
\hline \multirow[t]{2}{*}{$A I C O$} & $0.333 * * *$ & $23.607 * * *$ & $0.408 * * *$ \\
\hline & $(15.61)$ & $(13.72)$ & $(22.42)$ \\
\hline \multirow[t]{2}{*}{$R E S \_A N N O U N C E$} & $0.056 * * *$ & $6.494 * * *$ & $0.123 * * *$ \\
\hline & $(4.02)$ & (5.98) & (10.49) \\
\hline Year FE & Yes & Yes & Yes \\
\hline Industry FE & Yes & Yes & Yes \\
\hline $\operatorname{Adj} R^{2}$ & 0.819 & 0.347 & 0.200 \\
\hline$N$ & 22,873 & 22,873 & 22,873 \\
\hline
\end{tabular}




\section{Table 6: Negative News Coverage and Auditor Reporting Decisions}

Table 6 presents the results of our logit regression analysis of Equation (1). The dependent variables are measures of auditor reporting decisions determined by RES_ANNOUNCE and AICO. Our primary variables of interest are $\%$ RESTATEMENT_NEWS and \%AICO_NEWS. All variables are formally defined in Appendix 1. Robust standard errors are clustered by company. $T$-statistics are presented in parentheses below the corresponding coefficients. *, ${ }^{*}$, and $* * *$ indicate significance at the $0.10,0.05$, and 0.01 levels, respectively (based on two-tailed tests).

\begin{tabular}{|c|c|c|}
\hline & $\begin{array}{r}\text { RES_ANNOUNCE } \\
\text { (1) }\end{array}$ & $\begin{array}{r}\mathrm{AICO} \\
(2)\end{array}$ \\
\hline \%RESTATEMENT_NEWS & $\begin{array}{l}7.128 * * \\
(2.14)\end{array}$ & \\
\hline$\% A I C O \_N E W S$ & & $\begin{array}{l}16.895 * * \\
(2.42)\end{array}$ \\
\hline SIZE & $\begin{array}{l}-0.030 \\
(-1.01)\end{array}$ & $\begin{array}{l}-0.322 * * * \\
(-7.01)\end{array}$ \\
\hline$R O A$ & $\begin{array}{r}0.190 \\
(1.09)\end{array}$ & $\begin{array}{l}0.794 * * * \\
(3.06)\end{array}$ \\
\hline LOSS & $\begin{array}{l}0.282 * * * \\
(3.18)\end{array}$ & $\begin{array}{l}0.668 * * * \\
(5.83)\end{array}$ \\
\hline$I N V \_R E C$ & $\begin{array}{l}-0.105 \\
(-0.44)\end{array}$ & $\begin{array}{l}0.626^{*} \\
(1.79)\end{array}$ \\
\hline LEVERAGE & $\begin{array}{l}0.259 * * \\
(2.25)\end{array}$ & $\begin{array}{l}0.438 * * * \\
(2.94)\end{array}$ \\
\hline$B U S Y$ & $\begin{array}{r}0.010 \\
(0.14)\end{array}$ & $\begin{array}{l}-0.122 \\
(-1.03)\end{array}$ \\
\hline INTANGIBLES & $\begin{array}{l}0.346 * * \\
(1.98)\end{array}$ & $\begin{array}{l}0.883 * * * \\
(3.26)\end{array}$ \\
\hline AFILER & $\begin{array}{r}0.110 \\
(0.92)\end{array}$ & $\begin{array}{l}2.401 * * * \\
(9.27)\end{array}$ \\
\hline AFILER_LARGE & $\begin{array}{l}-0.054 \\
(-0.38)\end{array}$ & $\begin{array}{l}2.055 * * * \\
(6.56)\end{array}$ \\
\hline FOR_OPS & $\begin{array}{l}0.214 * * * \\
(2.70)\end{array}$ & $\begin{array}{l}0.244 * * \\
(2.00)\end{array}$ \\
\hline EXCHANGE & $\begin{array}{l}-0.049 \\
(-0.43)\end{array}$ & $\begin{array}{l}-0.467 * * * \\
(-2.74)\end{array}$ \\
\hline$I P O$ & $\begin{array}{l}0.686 * * * \\
(2.85)\end{array}$ & $\begin{array}{l}-0.791 \\
(-0.81)\end{array}$ \\
\hline ACQUISITIONS & $\begin{array}{l}-0.145 * \\
(-1.90)\end{array}$ & $\begin{array}{l}-0.101 \\
(-1.13)\end{array}$ \\
\hline TENURE & $\begin{array}{l}-0.426 * * * \\
(-5.21)\end{array}$ & $\begin{array}{l}-0.496 * * * \\
(-4.70)\end{array}$ \\
\hline$A U D \_S I Z E$ & $\begin{array}{r}0.320 \\
(1.48)\end{array}$ & $\begin{array}{l}-0.906 * * * \\
(-2.79)\end{array}$ \\
\hline$G C O$ & $\begin{array}{r}0.090 \\
(0.45)\end{array}$ & $\begin{array}{l}0.469 * * \\
(1.99)\end{array}$ \\
\hline INFLUENCE & $\begin{array}{l}0.148 * \\
(1.82)\end{array}$ & $\begin{array}{l}0.983 * * * \\
(9.47)\end{array}$ \\
\hline $\begin{array}{l}\text { Year FE } \\
\text { Industry FE }\end{array}$ & $\begin{array}{l}\text { Yes } \\
\text { Yes }\end{array}$ & $\begin{array}{l}\text { Yes } \\
\text { Yes }\end{array}$ \\
\hline $\begin{array}{l}\text { Pseudo } R^{2} \\
N\end{array}$ & $\begin{array}{r}0.033 \\
22,873\end{array}$ & $\begin{array}{r}0.106 \\
22,691\end{array}$ \\
\hline
\end{tabular}


Table 7: The Effect of High Negative News Coverage of Peer Firm

Table 7 presents the results of our OLS regression analysis of Equation (1). The dependent variables are measures of auditor attention determined by FEES, DELAY, and LATE. Our primary variable of interest is \%NEGATIVE (AICO/RESTATEMENT)_NEWS_PEER. The sample consists of all companies audited by firms other than the one with the highest amount of \%NEGATIVE (AICO/RESTATEMENT)_NEWS that period. All variables are formally defined in Appendix 1. Robust standard errors are clustered by company. $T$-statistics are presented in parentheses below the corresponding coefficients. ${ }^{*}, *$, and $* * *$ indicate significance at the $0.10,0.05$, and 0.01 levels, respectively (based on two-tailed tests).

Panel A: Audit Attention

\begin{tabular}{|c|c|c|c|}
\hline & $\begin{array}{r}\text { FEES } \\
(1)\end{array}$ & $\begin{array}{r}\text { DELAY } \\
(2) \\
\end{array}$ & $\begin{array}{r}\text { LATE } \\
(3)\end{array}$ \\
\hline$\% N E G A T I V E \_N E W S \_P E E R$ & $\begin{array}{l}0.406 * \\
(1.82)\end{array}$ & $\begin{array}{l}34.196 * * * \\
(3.02)\end{array}$ & $\begin{array}{l}0.345 * * \\
(2.30)\end{array}$ \\
\hline Controls & Yes & Yes & Yes \\
\hline Year FE & Yes & Yes & Yes \\
\hline Industry FE & Yes & Yes & Yes \\
\hline$\overline{A d j} R^{2}$ & 0.819 & 0.344 & 0.203 \\
\hline$N$ & 16,957 & 16,957 & 16,957 \\
\hline
\end{tabular}

Panel B: Audit Attention for Adverse ICO and Adverse ICO News

\begin{tabular}{lccc}
\hline & FEES & DELAY & LATE \\
& $(1)$ & $(2)$ & $(3)$ \\
\hline \%AICO_NEWS_PEER & 1.104 & 31.210 & 0.010 \\
& $(1.52)$ & $(0.85)$ & $(0.02)$ \\
AICO & $0.266 * * *$ & $10.845 * * *$ & $0.319 * * *$ \\
& $(5.97)$ & $(3.24)$ & $(8.24)$ \\
AICO $\boldsymbol{x}$ \%AICO_NEWS_PEER & $\mathbf{3 . 8 2 9}$ & $\mathbf{8 0 2 . 2 7 3} * * *$ & $\mathbf{6 . 2 3 8} * * *$ \\
& $\mathbf{( 1 . 6 1 )}$ & $\mathbf{3 . 4 0}$ & $\mathbf{( 3 . 1 4 )}$ \\
Controls & Yes & Yes & Yes \\
Year FE & Yes & Yes & Yes \\
Industry FE & Yes & Yes & Yes \\
\hline Adj $R^{2}$ & 0.819 & 0.351 & 0.205 \\
$N$ & 16,957 & 16,957 & 16,957 \\
\hline
\end{tabular}

Panel V: Audit Attention for Restatement Announcement and Restatement News

\begin{tabular}{|c|c|c|c|}
\hline & $\begin{array}{r}\text { FEES } \\
(1)\end{array}$ & $\begin{array}{r}\text { DELAY } \\
(2)\end{array}$ & $\begin{array}{r}\text { LATE } \\
(3)\end{array}$ \\
\hline \%RESTATEMENT_NEWS_PEER & $\begin{array}{l}0.846 * * \\
(2.16)\end{array}$ & $\begin{array}{c}40.130 * * \\
(2.23)\end{array}$ & $\begin{array}{l}0.461 * \\
(1.84)\end{array}$ \\
\hline RES_ANNOUNCE & $\begin{array}{l}0.008 \\
(0.29)\end{array}$ & $\begin{array}{l}-4.386 * * \\
(-2.00)\end{array}$ & $\begin{array}{l}-0.006 \\
(-0.27)\end{array}$ \\
\hline \multicolumn{4}{|l|}{ RES ANNOUNCEX } \\
\hline \%RESTATEMENT_NEWS_PEER & $\begin{array}{l}1.498 \text { * } \\
(1.89)\end{array}$ & $\begin{array}{c}327.367 * * * \\
(3.71)\end{array}$ & $\begin{array}{l}4.056 * * * \\
(6.16)\end{array}$ \\
\hline Controls & Yes & Yes & Yes \\
\hline Year FE & Yes & Yes & Yes \\
\hline Industry FE & Yes & Yes & Yes \\
\hline$\overline{A d j} R^{2}$ & 0.819 & 0.351 & 0.210 \\
\hline$N$ & 16,957 & 16,957 & 16,957 \\
\hline
\end{tabular}


Table 8: Negative News Coverage and Client Switching Behavior

Table 8 presents the results of our regression analysis of Equation (1). The dependent variables are measures of client switching behavior determined by INCOMING_CLIENT, OUTGOING_CLIENT and OVERALL_FIRM_GROWTH. Our primary variable of interest is \%NEGATIVE_NEWS. All variables are formally defined in Appendix 1 . Robust standard errors are clustered by company. $T$-statistics are presented in parentheses below the corresponding coefficients. *, $* *$, and $* * *$ indicate significance at the $0.10,0.05$, and 0.01 levels, respectively (based on two-tailed tests).

\begin{tabular}{|c|c|c|c|}
\hline & $\begin{array}{r}\text { INCOMING } \\
\text { CLIENT } \\
(1) \\
\end{array}$ & $\begin{array}{r}\text { OUTGOING } \\
\text { CIENT } \\
(2) \\
\end{array}$ & $\begin{array}{r}\text { OVERALL FIRM } \\
\text { GROWTH } \\
(3) \\
\end{array}$ \\
\hline \multirow[t]{2}{*}{$\% N E G A T I V E \_N E W S$} & $-3.704 * *$ & $3.230 * *$ & $-0.055 * * *$ \\
\hline & $(-2.24)$ & $(2.34)$ & $(-2.92)$ \\
\hline \multirow[t]{2}{*}{ SIZE } & -0.018 & $-0.334 * * *$ & $0.004 * * *$ \\
\hline & $(-0.39)$ & $(-8.12)$ & $(6.59)$ \\
\hline \multirow{2}{*}{$R O A$} & 0.204 & 0.289 & -0.003 \\
\hline & $(0.70)$ & $(1.63)$ & $(-0.69)$ \\
\hline LOSS & $\begin{array}{l}0.253 * * \\
(2.14)\end{array}$ & $\begin{array}{l}0.358 * * * \\
(3.69)\end{array}$ & $\begin{array}{l}-0.006 * * * \\
(-2.67)\end{array}$ \\
\hline$I N V_{-} R E C$ & $\begin{array}{l}0.746 * * \\
(2.11)\end{array}$ & $\begin{array}{l}0.902 * * * \\
(3.18)\end{array}$ & $\begin{array}{l}-0.012 * \\
(-1.96)\end{array}$ \\
\hline LEVERAGE & $\begin{array}{l}-0.059 \\
(-0.38)\end{array}$ & $\begin{array}{r}0.039 \\
(0.31)\end{array}$ & $\begin{array}{r}0.002 \\
(0.54)\end{array}$ \\
\hline$B U S Y$ & $\begin{array}{r}0.105 \\
(1.01)\end{array}$ & $\begin{array}{l}-0.073 \\
(-0.81)\end{array}$ & $\begin{array}{r}0.002 \\
(1.31)\end{array}$ \\
\hline INTANGIBLES & $\begin{array}{l}0.507 * * \\
(1.99)\end{array}$ & $\begin{array}{r}0.007 \\
(0.03)\end{array}$ & $\begin{array}{l}-0.000 \\
(-0.11)\end{array}$ \\
\hline AFILER & $\begin{array}{r}0.144 \\
(0.93)\end{array}$ & $\begin{array}{l}-0.538 * * * \\
(-4.86)\end{array}$ & $\begin{array}{l}0.016^{* * *} \\
(3.98)\end{array}$ \\
\hline AFILER_LARGE & $\begin{array}{l}-0.020 \\
(-0.11)\end{array}$ & $\begin{array}{l}-0.763 * * * \\
(-5.02)\end{array}$ & $\begin{array}{l}0.021 \text { *** } \\
(5.09)\end{array}$ \\
\hline FOR_OPS & $\begin{array}{c}0.011 \\
(0.10)\end{array}$ & $\begin{array}{r}0.090 \\
(1.00)\end{array}$ & $\begin{array}{l}-0.005 \text { *** } \\
(-2.62)\end{array}$ \\
\hline EXCHANGE & $\begin{array}{l}-0.484 * * * \\
(-3.32)\end{array}$ & $\begin{array}{l}-0.193 * \\
(-1.66)\end{array}$ & $\begin{array}{l}-0.004 \\
(-1.19)\end{array}$ \\
\hline$I P O$ & $\begin{array}{l}-0.787 \\
(-1.28)\end{array}$ & $\begin{array}{l}-1.511 * * * \\
(-2.96)\end{array}$ & $\begin{array}{l}0.024 * * * \\
(4.52)\end{array}$ \\
\hline ACQUISITIONS & $\begin{array}{l}0.229 * * \\
(2.19)\end{array}$ & $\begin{array}{l}0.160 * \\
(1.72)\end{array}$ & $\begin{array}{l}-0.002 \\
(-1.49)\end{array}$ \\
\hline$A U D \_S I Z E$ & $\begin{array}{l}-1.826 * * * \\
(-5.81)\end{array}$ & $\begin{array}{l}0.785 * * * \\
(2.75)\end{array}$ & $\begin{array}{l}-0.069 \text { *** } \\
(-14.05)\end{array}$ \\
\hline$G C O$ & $\begin{array}{l}-0.332 \\
(-1.10)\end{array}$ & $\begin{array}{l}0.556 * * * \\
(3.48)\end{array}$ & $\begin{array}{l}-0.031 * * * \\
(-2.74)\end{array}$ \\
\hline FIRM_RES_ANNOUNCE & $\begin{array}{c}-12.700 * \\
(-1.68)\end{array}$ & $\begin{array}{l}13.890 * * \\
(2.20)\end{array}$ & $\begin{array}{l}0.373 * * * \\
(3.60)\end{array}$ \\
\hline INFLUENCE & $\begin{array}{l}-0.575 * * * \\
(-5.11)\end{array}$ & $\begin{array}{l}-0.040 \\
(-0.41)\end{array}$ & $\begin{array}{l}-0.001 \\
(-0.86)\end{array}$ \\
\hline$A I C O$ & $\begin{array}{l}1.139 * * * \\
(7.70)\end{array}$ & $\begin{array}{l}1.432 * * * \\
(10.96)\end{array}$ & $\begin{array}{l}-0.027 * * * \\
(-3.81)\end{array}$ \\
\hline RES_ANNOUNCE & $\begin{array}{l}0.415 * * \\
(2.40)\end{array}$ & $\begin{array}{r}0.173 \\
(1.09)\end{array}$ & $\begin{array}{l}-0.003 \\
(-0.65)\end{array}$ \\
\hline Year FE & Yes & Yes & Yes \\
\hline Industry FE & Yes & Yes & Yes \\
\hline Pseudo/Adj $R^{2}$ & 0.050 & 0.113 & 0.304 \\
\hline$N$ & 22,741 & 21,149 & 19,776 \\
\hline
\end{tabular}

